\title{
DOMOIC acid, Pseudo-nitzschia spp and potential vectors at the base of the pelagic food web over the northern Patagonian coast, Southwestern Atlantic
} Bernd Krock ${ }^{\mathrm{h}}$

\author{
a Instituto Argentino de Oceanografía (IADO), Centro Científico Tecnológico Bahía Blanca, CONICET - Universidad Nacional del Sur, Camino La Carrindanga km 7 , \\ B8000FWB Bahía Blanca, Argentina \\ ${ }^{\mathrm{b}}$ Consejo Nacional de Investigaciones Científicas y Técnicas (CONICET), Godoy Cruz 2290, C1425FQB Ciudad Autónoma de Buenos Aires, Argentina \\ ${ }^{\mathrm{c}}$ Facultad Regional Bahía Blanca, Universidad Tecnológica Nacional, 11 de Abril 461, B8000LMI Bahía Blanca, Argentina

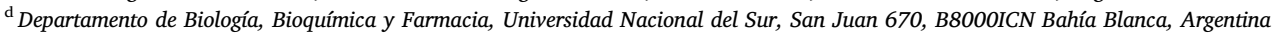 \\ e División Ficología, Facultad de Ciencias Naturales y Museo, Universidad Nacional de La Plata, Paseo del Bosque s/n, B1900FWA La Plata, Argentina \\ ${ }^{\mathrm{f}}$ Centro para el Estudio de Sistemas Marinos, CESIMAR - CONICET, Boulevard Brown 2915, U9120ACD Puerto Madryn, Argentina \\ ${ }^{\mathrm{g}}$ Instituto Patagónico del Mar, Boulevard Brown 3051, U9120ACD Puerto Madryn, Argentina \\ ${ }^{\mathrm{h}}$ Alfred Wegener Institut - Helmholtz Zentrum für Polar - und Meeresforschung, Chemische Ökologie, Am Handelshafen 12, 27570 Bremerhaven, Germany
}

\section{A R T I C L E I N F O}

\section{Keywords:}

Argentine Sea

Calanidae copepodites

Calanidae nauplii

Cladocerans

Domoic acid vectors

Pseudo-nitzschia australis

P. pungens

P. pseudodelicatissima

Small copepods

Toxin producers

\begin{abstract}
A B S T R A C T
Plankton composition and density, and domoic acid (DA) content in microplankton and mesozooplankton were assessed over the northern Patagonian coastal shelf in late austral summer 2013. Maximum values of DA in these two plankton fractions as well as maximum densities of both Pseudo-nitzschia spp. (mainly the toxigenic P. australis) and DA potential vectors were only detected on the southern coast of San Matías Gulf and the eastern coast of Valdés Peninsula. In this zone, waters were characterized by low temperature, high nitrate, and intermediate values of silicic acid and phosphate. Based on the high association between the DA values recorded and the values of either microand mesozooplankton grazer density or biomass, we inferred that DA transfer from Pseudo-nitzschia spp. occurred largely through the small copepods Euterpina acutifrons and Oithona nana, Calanidae nauplii and Calanidae copepodites, Noctiluca scintillans, and euphausiid developmental stages. Small copepods, Calanidae nauplii and copepodites, and cladocerans were proposed as novel DA vectors although this suggestion requires experimental confirmation. This study provides the first lines of evidence of the co-occurrence of Pseudo-nitzschia spp. blooms with DA production and accumulation in mesozooplanktonic grazers at the base of the food web and of the environmental and oceanographic conditions that seem to favor these processes over the northern Patagonian shelf coasts.
\end{abstract}

\section{Introduction}

Species of the marine diatom (Bacillariophyceae) genus Pseudo-nitzschia and Nitzschia include species known as producers of domoic acid (DA), a hydrophilic and secondary amino acid neurotoxin responsible for amnesic shellfish poisoning (ASP). During blooms of toxigenic species (HABs), DA is transferred to higher organisms through the pelagic food web and is accumulated by intermediate vectors, such as microheterotrophs, copepods, euphausiids, shellfish, and fish (Lincoln et al., 2001; Lefebvre et al., 2002; Bargu et al., 2003; Costa and Garrido, 2004;
Olson et al., 2008; Leandro et al., 2010b; Olson and Lessard, 2010; Tammilehto et al., 2012). As this neurotoxin affects top predators and shellfish consumers (Scholin et al., 2000; Fire et al., 2010; Lelong et al., 2012; McHuron et al., 2013), intoxication with DA becomes a risk to human health and marine wildlife (Lefebvre et al., 2002).

A total of twenty-six species of Pseudo-nitzschia (Peragallo) have been identified as toxigenic to date (Bates et al., 2018; Lundholm, 2019). They have the ability to adapt to different conditions and are found worldwide (Bates and Trainer, 2006; Bates et al., 2018 and references therein) mainly at shelf zones as well as in far offshore regions (Marchetti et al., 2006).

\footnotetext{
Abbreviations: DA, domoic acid; MiP, microplankton; MezooP, mesozooplankton; VP, Valdés Peninsula; SMG, San Matías Gulf; NG, Nuevo Gulf; SJG, San José Gulf. * Corresponding author at: Instituto Argentino de Oceanografía (IADO), Centro Científico Tecnológico Bahía Blanca, CONICET - Universidad Nacional del Sur, Camino La Carrindanga km 7, B8000FWB Bahía Blanca, Argentina.

E-mail address: bmhoffme@criba.edu.ar (M.S. Hoffmeyer).
} 
Pseudo-nitzschia blooms can reach high density with concentrations of up to $10^{7}$ cells per liter, as reported on the western coasts of the USA during intensive ASP events (Trainer et al., 2012 and references therein). These blooms, which occur under particular conditions of temperature and salinity, are mainly stimulated by diverse sources of macronutrients, upwelling-mixing processes, and riverine inputs plus coastal eutrophication (Trainer et al., 2000; Parsons et al., 2002; Loureiro et al., 2009). In addition, the hydrographic conditions can have a synergistic impact on the structure and dynamics of planktonic assemblages becoming key to understand the trophic interactions between Pseudo-nitzschia spp. and its potential consumers (Bates et al., 2018). Pseudo-nitzschia blooms may be unusually massive and dangerous. An example of such blooms occurred during the spring of 2015, immediately after an extraordinary warming oceanographic phenomenon observed from 2013 to 2015 along the California Current System (CCS) (Trainer et al., 2019) called "the Blob" -moving from the north- advanced over the western coast of USA. This $\mathrm{HAB}$ which developed in cool and macronutrient-rich coastal upwelling waters was reported to have unusually very high densities of toxigenic Pseudo-nitzschia spp. (mainly P. australis) and high DA peaks (McCabe et al., 2016; McKibben et al., 2017). The harmful consequences resulting from the food web transfer of DA produced closures of Dungeness crab, rock crab, razor clam and other fisheries and a high mortality rate of numerous marine mammals and seabirds. Coastal communities also suffered severe economic losses due -in part- to these fisheries closures (Trainer et al., 2019).

Although some evidence has been collected on microzooplankton (mainly heterotrophic dinoflagellates) grazing on Pseudo-nitzschia spp. (Kjaeret et al. 2000; Buck et al., 2005; Olson and Lessard, 2010), this phenomenon does not seem to be crucial either for DA transfer or Pseudonitzschia spp. mortality (Olson et al., 2008). Other studies have provided evidence of Pseudo-nitzschia spp. ingestion by the large dinoflagellate Noctiluca scintillans (cells in food vacuoles, NW Spain, Escalera et al., 2007). On the other hand, copepods and euphausiids are two recognized and important filter feeder crustacean groups within mesozooplankton which consume toxigenic Pseudo-nitzschia spp. and accumulate DA (Trainer et al., 2012; Bates et al., 2018). They have been reported to be the main primary-secondary DA vectors at the base of pelagic food webs (Bargu et al., 2003; Turner, 2014 and references therein). Experimental studies on grazing have demonstrated that copepods feeding upon Pseudonitzschia spp. do not diminish their fecundity whereas DA accumulates in tissues and fecal pellets as observed in Acartia tonsa, A. clausi, Calanus finmarchicus, C. glacialis, C. hyperboreous, Temora longicornis and Paracalanus parvus (Lincoln et al., 2001; Tester et al., 2001; Maneiro et al., 2005; Leandro et al., 2010a, Leandro et al., 2010b; Tammilehto et al., 2012, 2015; Harðardóttir et al., 2015; Miesner et al., 2016; García, unpublished results) and the krill Euphausia superba (Bargu et al., 2003). Studies on DA consumption and grazing selectivity (Lincoln et al., 2001; Maneiro et al., 2005; Leandro et al., 2010b; Harðardóttir et al., 2015; Miesner et al., 2016) suggest that copepods do not reduce their grazing rates when DA producers are present and that they do not show any trophic preference for non-toxigenic cells. Nevertheless, they seem to suffer from a temporary physiological incapacitation after grazing for some time (e.g., C. finmarchicus and C. hyperboreus grazing on Pseudonitzschia seriata: Tammilehto et al., 2012, 2015). All the above-mentioned planktonic groups are assumed to transfer DA to higher trophic levels, such as planktivorous fish, birds and humpback, right and blue whales, and DA is thought to be spread through fish as well as through other organisms of benthic food chains, such as bottom filter feeders (mollusks and even scavengers) (Lefebvre et al., 2002a; Trainer et al., 2012 and references therein). This promotes not only a continuous vertical flux of DA (marine snow) during Pseudo-nitzschia blooms but also a source of DA in the sediments (Burns and Ferry, 2007; Sekula-Wood et al., 2009; Schnetzer et al., 2017).

The presence of Pseudo-nitzschia spp. in the Argentine Sea has been extensively documented (Negri and Inza, 1998; Ferrario et al., 1999; Sastre et al., 2001; Negri et al., 2004; Almandoz et al., 2007; Sunesen et al., 2009; Krock et al., 2015). A total of 13 Pseudo-nitzschia species have been recorded in this region (Almandoz et al., 2017) from which $P$. australis Frenguelli is mainly associated with the detection of DA. A few toxic events were recorded along Mar del Plata coast in June 2000 (Negri et al., 2004) and in Valdés Peninsula (VP) coastal waters in October 2005 (Sastre et al., 2007). During the former event, which was attributed to a $P$. australis bloom, high levels of DA were detected in plankton, mussels, and in anchovies' stomachs (Engraulis anchoita) (Negri et al., 2004). Likewise, high levels of DA associated with high density of $P$. fraudulenta (Cleve) Hasle and $P$. pungens (Grunow ex Cleve) Hasle were also registered in mussels from Nuevo Gulf (NG) (Sastre et al., 2007). Further studies have been performed not only recording peaks of Pseudo-nitzschia density (mainly $P$. australis) but also detecting DA content in microplankton and mesozooplankton in the northern Patagonian gulfs, namely San José (SJG) and Nuevo (NG) during spring (Cadaillón, 2012; D'Agostino et al., 2017, 2018). Cadaillón (2012) observed the co-occurrence of DA in phytoplankton and in zooplankton samples for the first time in SJG, at concentrations exceeding the permitted limit value of DA in mollusks for human consumption, which was indicative of the transfer of this toxin through zooplankton vectors. Further research reported the presence of broken frustules of Pseudo-nitzschia spp. and remains of copepods, mostly of the large copepod Calanus australis, in feces of the southern right whales in the northern Patagonian gulfs (D'Agostino et al., 2015, 2016). These findings strongly suggest that $C$. australis could be one of the vectors of Pseudo-nitzschia spp. and DA to whales and that these mammals are exposed to DA during their reproductive stay in the northern Patagonian gulfs (D'Agostino et al., 2015; Wilson et al., 2015). D'Agostino et al. (2017) showed, in turn, the occurrence of DA transfer from Pseudo-nitzschia spp. to mesozooplankton consumers suspected to be DA vectors, such as the large copepods $C$. australis and Calanoides carinatus, and Paracalanus parvus.

Specific data on DA content and distribution in auto- and heterotrophic size plankton fractions along the Argentine Sea are still lacking, calling for further research, and its transfer at the base of the pelagic food web remains unclear. Therefore, the aims of the present study were to: i) analyze the spatial variability of DA content in microplankton and mesozooplankton, ii) assess the composition and density of these plankton fractions related to environmental and oceanographic conditions, and iii) draw inferences as to which zooplankton grazers are likely to be the main DA vectors at the base of the pelagic food web on the northern Patagonian coastal shelf in late summer.

\section{Material and methods}

\subsection{Sampling}

Environmental variables were recorded and plankton sampling was performed on board the research vessel "Dr. Bernardo Houssay" during the H032013 oceanographic expedition. Sixteen stations ( $\sim 41$ and $\left.43^{\circ} \mathrm{S}\right)$ which belonged to the second leg (K2) of this expedition along San Matías Gulf (SMG) coasts and Valdés Peninsula (VP) eastern-southern coasts were visited from March 18th to 22nd, 2013 (Fig. 1). These stations were numbered -slightly differently from the study of Almandoz et al. (2017)- as 1, 2, 3, 4, 5, 6, 7, 8, 9, 10 A,10 B, 11, 12, 13 and 14. Station 10 , i.e. st. $10 \mathrm{~A}$ and st. $10 \mathrm{~B}$, was the only station sampled twice. The mesozooplankton net samples from st. 15 were not available due to technical problems. Data on Pseudo-nizschia spp. density and DA content in microplankton (Mip) used in the present study were previously reported by Almandoz et al. (2017) but within another context.

\subsection{Environmental conditions}

Temperature, salinity, dissolved oxygen, and $\mathrm{pH}$ were measured in situ using an YSI ${ }^{\oplus} 556$ MPS probe. Seawater was collected at 0 and 10 m-depth, using a Niskin bottle and $1 \mathrm{~L}$ was filtered for chlorophyll- $a$ (Chl- $a$ ) analysis through $47 \mathrm{~mm} \mathrm{GF} / \mathrm{F}$ Whatman ${ }^{\circledR}(0.7 \mu \mathrm{m})$ filter. An 


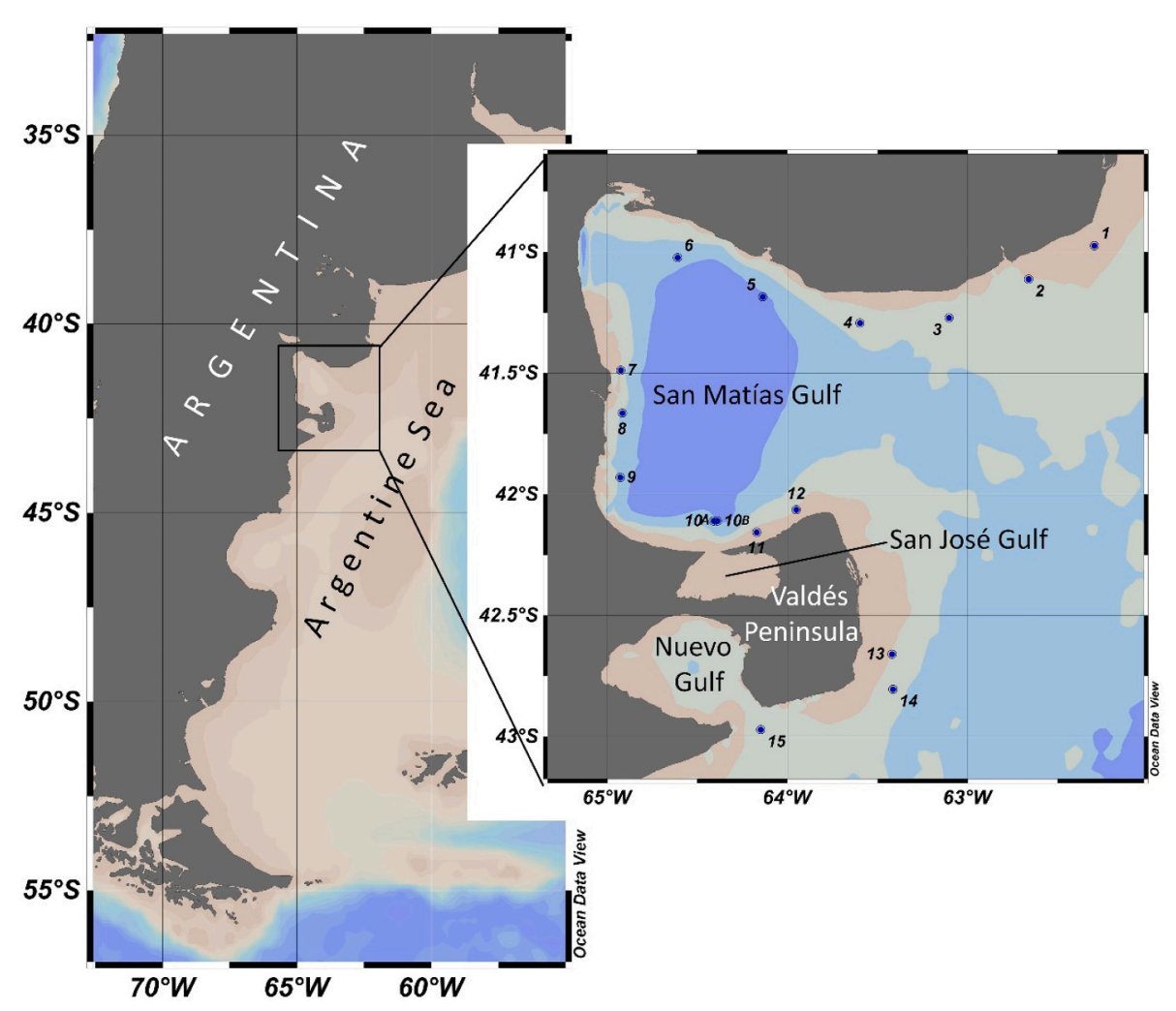

Fig. 1. Study area showing the location of sampling stations on the Northern Patagonian shelf.

aliquot of the filtered water was sampled for nitrate + nitrite, phosphate and silicic acid analyses in $250 \mathrm{ml}$ acid cleaned bottles. Filters and bottles with seawater were preserved at $-20{ }^{\circ} \mathrm{C}$ until the laboratory analyses were performed.

Nutrient concentrations were determined using a Skalar San Plus ${ }^{\circledast}$ autoanalyzer, following Skalar analytical methods (Skalar Analytical ${ }^{\circledR}$, V.B, 2005a, b and c. Given the low concentration of nitrite, the nitrite + nitrate concentration was expressed as nitrate. Chl- $a$ was extracted by acetone $90 \%$ and quantified in a Turner Designs ${ }^{\circledR}$ fluorometer Model 111 according to Strickland and Parsons (1972).

\subsection{Chlorophyll-a remote sensing data}

MODIS-Aqua spatially extracted Level-2 files were acquired for the SMG region from the NASA ocean color web page (oceancolor.gsfc. nasa.gov) for the dates concurrent with the oceanographic expedition (see Fig. A.1, Appendix A). The aim of this analysis was to determine a) the spatio-temporal variability of satellite-sourced Chl- $a$ levels and b) the relationships between Chl- $a$ (in-situ and satellite concentration values), variability and density of Pseudo-nitzschia spp. and total phytoplankton density in the study area. Four images (March 18th, 19th, 21st and 22nd, 2013) were chosen because of their relatively low cloud covering over the area of interest for the sampling period. The standard Chl- $a$ product derived from the OC3 algorithm (OC3M updated version after the 2014 reprocessing) was requested and mapped to a WGS84 reference system (datum WGS84, ellipsoid WGS84).

\subsection{Plankton}

In this study we have focused on microplankton (MiP) and mesozooplankton (MezooP) communities. According to plankton size classification by Sieburth et al. (1978), microplankton is the $20 \mu \mathrm{m}-200 \mu \mathrm{m}$ size fraction composed of i- phytoplankton (i.e. all microalgae belonging to this fraction) and ii- microzooplankton (i.e. heterotrophicmixotrophic protists plus small-sized developmental stages of copepods and other invertebrates). Mesozooplankton, in turn, is the $0.2 \mathrm{~mm}-20 \mathrm{~mm}$ size fraction (i.e. a part of metazooplankton) mainly composed of heterotrophic metazoans, mostly crustaceans and cnidarians. It may also accidentally present diatom chains, other larger phytoplanktonic aggregates or the large dinoflagellate $N$. scintillans.

At each sampling station, two seawater samples were collected using a Niskin bottle at the surface and at $5 \mathrm{~m}$-depth and fixed in Lugol's solution ( $4 \%$ final concentration) for MiP taxonomic and quantitative analyses (Almandoz et al., 2017). Net tow samples of MiP and MezooP were also collected to assess the direct relationships between the occurrence and density of Pseudo-nitzschia spp. and DA content in MiP and MezooP (DA MiP and DA MezooP) (i.e., primarily suspected to be DA contained in Pseudo-nitzschia cells and in the body of Pseudo-nitzschia spp. consumers and DA vectors, respectively). A MiP net sample was taken using a $20 \mu \mathrm{m}$-mesh net, $0.40 \mathrm{~m}$ mouth diameter, model 438,030, HydroBios (Kiel, Germany) by means of a vertical tow through the upper $20 \mathrm{~m}$ of the seawater column. Samples were fixed in formalin ( $2 \%$ final concentration). The theoretical estimate of the volume filtered by this net was $2.51 \mathrm{~m}^{3}$. The processing of each MiP net sample and size fractioning (50 and $200 \mu \mathrm{m}$ meshes) was carried out as described in Almandoz et al. (2017). The retained aliquots were concentrated in $2 \mathrm{~mL}$ cryovials, pelleted by centrifugation (Eppendorf 5415 D, Hamburg, Germany) (3220 x $\mathrm{g}, 15 \mathrm{~min}$ at $4{ }^{\circ} \mathrm{C}$ ), and frozen for DA chemical extraction and quantification. DA concentrated in each MiP sample was expressed as the sum of DA content found in $20-50$ and $50-200 \mu \mathrm{m}$ size fractions.

At each sampling station, two MezooP net samples were also collected by means of vertical tows $(30-0 \mathrm{~m})$ with a $200 \mu \mathrm{m}$-mesh net ( $0.30 \mathrm{~m}$ mouth diameter) using a mechanical flow meter (HydroBios, Kiel, Germany) in order to estimate the seawater volume filtered by the net. The mean volume filtered by this net was $2.12 \mathrm{~m}^{3}$. One net tow sample was fixed in formalin (final concentration 4\%) for taxonomic and qualitative-quantitative analyses, and the other one was concentrated onto a GF/F Millipore filter by gentle vacuum filtration, placed in micro vial and frozen $\left(-20{ }^{\circ} \mathrm{C}\right)$ for subsequent DA chemical analysis and quantification. 


\subsection{Identification and quantification of MiP and MezooP}

MiP net samples were analyzed for identification and quantification of Pseudo-nitzschia species within phytoplankton, as detailed in Almandoz et al. (2017). Briefly, total Pseudo-nitzschia spp. cell density was determined by counting aliquots of $1 \mathrm{ml}$ in Sedgewick-Rafter chamber with a phase-contrast Leica DMIL LED inverted microscope and expressed in cells per net tow (cells $\mathrm{NT}^{-1}$ ). The relative cell density of Pseudo-nitzschia species was calculated by examining cleaned cell specimens (Prygiel and Coste, 2000) mounted on permanent slides with Naphrax mounting medium, with a Leica DM2500 phase-contrast microscope. All the valves on the whole slide were enumerated at $1000 \times$ as indicated in Almandoz et al. (2017). The species $P$. australis and $P$. fraudulenta were differentiated mainly by the presence/absence of a central interspace, which can be clearly detected at $1000 \times$ in cleaned frustules mounted on permanent slides with Naphrax. Total Pseudo-nitzschia density -expressed per net towwas multiplied by the relative densities estimated by the enumeration on permanent slides to obtain the density of different species. Scanning electron microscopy observations were also carried out to confirm species identity with a Jeol JSM-6360 LV microscope. Details on SEM morphology of the unidentified specimens belonging to the $P$. pseudodelicatissima species complex were also reported by Almandoz et al. (2017).

MiP net samples were analyzed for microzooplankton identification and quantification. Taxonomic groups were identified to the lowest possible taxonomic level by consulting appropriate literature (Boltovskoy, 1981, 1999; Kogan, 2005; Petz, 1999) and their quantification was performed following the Utermöhl method after Hasle (1978). Samples were well homogenized and aliquots of $10 \mathrm{~mL}$ were allowed to settle for $24 \mathrm{~h}$ in counting chambers (HydroBios, Kiel, Germany). All organisms present in the chamber were subsequently counted under a Nikon Eclipse TS100 inverted microscope. The density of species and groups was expressed as individuals per net tow (ind $\mathrm{NT}^{-1}$ ).

The qualitative analysis of MezooP in the samples were carried out under a Wild M5 or a Nikon SMZ 1500 (Nikon, Tokyo, Japan) stereomicroscope. The identification of organisms in the samples was performed to the lowest possible taxonomic level by consulting appropriate literature (Boltovskoy, 1999; Bradford-Grieve et al., 1999). Quantitative analysis was carried out on Bogorov-type chambers (HydroBios, Kiel, Germany) under a Nikon SMZ 1500 stereomicroscope. Counting of MezooP was performed either by counting several aliquots of up to $10 \%$ of the sample volume or by total counting, according to the a priori thick estimate of MezooP amount in samples. Density values were expressed as individuals per net tow (ind $\mathrm{NT}^{-1}$ ).

MezooP biomass values were also calculated for all taxa present in samples and for total mesozooplankton. Individual biomass values were previously estimated according to data from the literature (Fernandez Aráoz, 1991; Ara, 2001; Muxagata et al., 2012; Garcia et al., 2016). Biomass values of MezooP groups, such as copepods and cladocerans, or species were expressed in terms of dry weight per net tow and in relative biomass (\%).

As food intake and grazing rates in planktonic copepods depend on body size, different biomasses may produce distinct food intakes (Peters and Downing, 1984). Grazing rates for the principal copepod species found in our samples were estimated taking into account the individual grazing rate values retrieved from the literature of Calanus glacialis, $C$. hyperboroeus, C. finmarchicus, Acartia clausi, A. tonsa and Temora longicornis (Lincoln et al., 2001; Maneiro et al., 2005; Leandro et al., 2010a; Leandro et al., 2010b; Tammilehto et al., 2015). These copepod species were either the same as those we observed in our samples or they were other species with approximately the same body size as that of the copepod species recorded in our study.

\subsection{DA extraction and chemical analysis in MiP and MezooP samples}

Cell concentrates from the MiP net samples were suspended in $500 \mu \mathrm{L}$ methanol and subsequently homogenized with $0.9 \mathrm{~g}$ of lysing matrix D by reciprocal shaking at maximum speed $\left(6.5 \mathrm{~m} \mathrm{~s}^{-1}\right)$ for $45 \mathrm{~s}$ in a Bio101
FastPrep instrument (Thermo Savant, Illkirch, France). After homogenization, samples were centrifuged at $16,100 \mathrm{xg}$ at $4{ }^{\circ} \mathrm{C}$ for $15 \mathrm{~min}$. The supernatants were transferred to spin-filters $(0.45 \mu \mathrm{m}$ pore-size, Millipore Ultrafree, Eschborn, Germany) and centrifuged for $30 \mathrm{~s}$ at $800 \mathrm{xg}$, followed by transfer to auto sampler vials. Filters containing MezooP samples were thawed and cut into halves. Half a filter from each station was used for the analysis of multiple lipophilic toxins and the other half for DA analysis. Each half filter was transferred into a FastPrep tube with $0.9 \mathrm{~g}$ of lysing matrix D. One $\mathrm{mL}$ of methanol was added to each sample and lipophilic toxin and DA were extracted as described above. The analysis of lipophilic and hydrophilic toxins including DA was performed by liquid chromatography coupled with tandem mass spectrometry (LC-MS/MS) as described in Krock et al. (2008). DA content in MiP and MezooP samples was expressed in $\mathrm{ng} \mathrm{NT}^{-1}$.

\subsection{Data analysis}

Bivariate correlations were performed among each pair of variables, such as density of different groups or taxa within MiP and MezooP and biomass/grazing rates of some MezooP groups with DA content in each fraction and environmental variables. As most variables did not meet linear assumptions even after transformation, the Spearman rank correlation coefficient $\left(r_{s}\right)$ was used (Zar, 1999; Casanoves et al., 2012).

A Principal Component Analysis was also carried out using a correlation matrix and standardization of variables to analyze the ordering of multivariate data corresponding to the variables that were found to be strongly correlated with each other, with DA in both plankton fractions and with the environmental variables. These variables were: DA-producing species density taken from Almandoz et al. (2017), total copepods and particular copepod species density, DA MiP, DA MezooP and environmental variables. The statistical software used in the present study was InfoStat (Di Rienzo et al., 2016).

\section{Results}

\subsection{Environmental conditions}

A summary of the environmental conditions found in the study area is shown in Table 1. Temperature showed a gradual decrease along the oceanographic cruise track. A significant and positive correlation $(p<0.05)$ was found between temperature and salinity and dissolved oxygen $\left(r_{s}=0.51\right.$ and 0.58 respectively; $n=16$ in both cases) whereas a negative correlation was found between temperature and nitrate and phosphate $\left(r_{s}=-0.88\right.$ and -0.57 respectively; $\mathrm{n}=16$ in both cases). Nitrate increased along the cruise track and revealed a significant and negative correlation $(\mathrm{p}<0.05)$ with salinity $\left(\mathrm{r}_{\mathrm{s}}=-0.52 ; \mathrm{n}=16\right)$ and dissolved oxygen $\left(\mathrm{r}_{\mathrm{s}}=-0.67\right.$; $\mathrm{n}=16$ ). Salinity, $\mathrm{pH}$, and silicate at stations 1 and 2 showed the influence of Negro River discharge (sts. 1 and 2, see Fig. 1). Silicate was observed to be significantly negatively correlated $(\mathrm{p}<0.05)$ with salinity $\left(\mathrm{r}_{\mathrm{s}}=-0.53\right.$; $\mathrm{n}=16)$ and $\mathrm{pH}\left(\mathrm{r}_{\mathrm{s}}=-0.73 ; \mathrm{n}=16\right)$. Chl- $a$ concentrations (between 0.3 and $2.3 \mathrm{mg} \mathrm{m}^{-3}$ ) were found to be higher in the sector close to the northern and western coasts of SMG in coincidence with patches of maximum concentrations observed in the satellite images (Table 1 and Fig. A.1, Appendix A). N:P ratios varied between $\sim$ zero and 5 . At the northern stations (1-9) values were found to fluctuate from $\sim$ zero to 1.5 whereas they clearly became higher at the southern stations (10-15) with a maximum peak at st. 13. $\mathrm{N}: \mathrm{Si}$ ratios were also found to be higher at the southern stations with respect to those at the northern stations (10-15) and P:Si ratios were observed to be low (0 to 0.5 ) at all stations. During our oceanographic expedition, a phytoplankton bloom observed by the MODIS sensor showed high concentrations of Chl- $a\left(2.5 \mathrm{mg} \mathrm{m}^{-3}\right)$ along the western coast of SMG from March 18th to 21st, 2013 (see Fig. A.1, Appendix A).

3.2. Composition, density and distribution of Pseudo-nitzschia spp., MiP and $\mathrm{MezooP}$

The density of Pseudo-nitzschia spp. from MiP net samples showed a 
Table 1

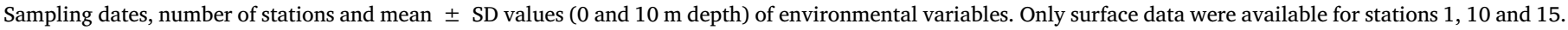

\begin{tabular}{|c|c|c|c|c|c|c|c|c|c|}
\hline Date & st. & Temperature $\left({ }^{\circ} \mathrm{C}\right)$ & Salinity $\left(\mathrm{g} \mathrm{L}^{-1}\right)$ & $\begin{array}{l}\text { Dissolved Oxygen } \\
\left(\mathrm{mg} \mathrm{L}^{-1}\right)\end{array}$ & $\mathrm{pH}$ & Nitrate $(\mu \mathrm{M})$ & Phosphate $(\mu \mathrm{M})$ & Silicic acid $(\mu \mathrm{M})$ & $\begin{array}{l}\text { Chlorophyll- } a \\
\left(\mathrm{mg} \mathrm{m}^{-3}\right)\end{array}$ \\
\hline 03/18/2013 & 1 & 15.80 & 33.50 & 7.12 & - & 1.89 & 1.45 & 11.44 & 0.63 \\
\hline $03 / 18 / 2013$ & 2 & $17.90 \pm 0.00$ & $33.60 \pm 0.14$ & $7.55 \pm 0.02$ & $7.78 \pm 0.10$ & $0.20 \pm 0.09$ & $1.14 \pm 0.01$ & $6.68 \pm 0.39$ & $0.70 \pm 0.09$ \\
\hline 03/18/2013 & 3 & $17.55 \pm 0.49$ & $34.45 \pm 0.07$ & $7.31 \pm 0.12$ & $7.93 \pm 0.07$ & $0.34 \pm 0.14$ & $0.98 \pm 0.02$ & $2.30 \pm 0.01$ & $1.25 \pm 0.00$ \\
\hline $03 / 19 / 2013$ & 4 & $17.00 \pm 0.14$ & $34.25 \pm 0.07$ & $7.55 \pm 0.23$ & $7.94 \pm 0.01$ & $0.90 \pm 0.18$ & $0.91 \pm 0.23$ & $2.79 \pm 0.27$ & $2.26 \pm 0.18$ \\
\hline 03/19/2013 & 5 & $17.55 \pm 0.49$ & $34.40 \pm 0.14$ & $7.44 \pm 0.11$ & $7.93 \pm 0.01$ & $0.44 \pm 0.13$ & $0.99 \pm 0.01$ & $2.48 \pm 0.37$ & $1.32 \pm 0.45$ \\
\hline $03 / 19 / 2013$ & 6 & $16.90 \pm 0.28$ & $34.40 \pm 0.14$ & $7.67 \pm 0.01$ & $7.97 \pm 0.01$ & $0.21 \pm 0.01$ & $1.06 \pm 0.01$ & $2.96 \pm 0.28$ & $0.93 \pm 0.29$ \\
\hline $03 / 20 / 2013$ & 7 & $16.75 \pm 0.07$ & $34.40 \pm 0.00$ & $7.37 \pm 0.07$ & $7.86 \pm 0.04$ & $0.41 \pm 0.04$ & $0.84 \pm 0.09$ & $5.91 \pm 4.16$ & $1.01 \pm 1.42$ \\
\hline 03/20/2013 & 8 & $16.30 \pm 0.14$ & $34.35 \pm 0.07$ & $7.45 \pm 0.13$ & $7.86 \pm 0.02$ & $1.30 \pm 0.15$ & $1.09 \pm 0.07$ & $5.97 \pm 3.18$ & $1.38 \pm 0.18$ \\
\hline $03 / 20 / 2013$ & 9 & $16.15 \pm 0.07$ & $34.30 \pm 0.00$ & $7.48 \pm 0.04$ & $7.86 \pm 0.04$ & $1.19 \pm 0.60$ & $0.97 \pm 0.09$ & $5.13 \pm 1.55$ & $1.95 \pm 0.80$ \\
\hline $03 / 21 / 2013$ & $10 \mathrm{~A}$ & 15.90 & 34.00 & 7.21 & 7.86 & 2.58 & 1.18 & 3.68 & 1.50 \\
\hline $03 / 21 / 2013$ & $10 \mathrm{~B}$ & $15.90 \pm 0.00$ & $34.15 \pm 0.07$ & $7.42 \pm 0.00$ & $7.88 \pm 0.05$ & $2.25 \pm 0.46$ & $1.04 \pm 0.13$ & $2.87 \pm 0.77$ & $1.01 \pm 0.18$ \\
\hline $03 / 21 / 2013$ & 11 & $15.65 \pm 0.49$ & $34.15 \pm 0.07$ & $7.38 \pm 0.24$ & $7.82 \pm 0.00$ & $3.05 \pm 0.03$ & $1.24 \pm 0.03$ & $3.59 \pm 0.06$ & $1.15 \pm 1.39$ \\
\hline $03 / 21 / 2013$ & 12 & $15.80 \pm 0.28$ & $33.95 \pm 0.21$ & $7.17 \pm 0.05$ & $7.82 \pm 0.03$ & $5.85 \pm 1.68$ & $1.16 \pm 0.02$ & $4.76 \pm 1.66$ & $0.94 \pm 0.44$ \\
\hline 03/21/2013 & 13 & $15.95 \pm 0.07$ & $33.95 \pm 0.07$ & $6.88 \pm 0.08$ & $7.92 \pm 0.07$ & $2.61 \pm 0.04$ & $0.83 \pm 0.07$ & $4.07 \pm 1.94$ & $0.34 \pm 0.00$ \\
\hline $03 / 22 / 2013$ & 14 & 16.10 & 34.10 & 6.82 & 7.82 & 2.36 & 1.02 & 3.32 & 0.63 \\
\hline $03 / 22 / 2013$ & 15 & $15.70 \pm 0.28$ & $34.05 \pm 0.07$ & $7.01 \pm 0.06$ & $7.93 \pm 0.03$ & $3.39 \pm 0.26$ & $1.20 \pm 0.13$ & $3.25 \pm 0.29$ & $1.01 \pm 0.18$ \\
\hline
\end{tabular}

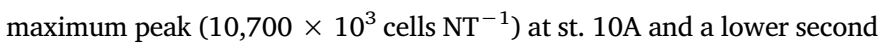
peak $\left(\sim 5000 \times 10^{3}\right.$ cells NT $\left.{ }^{-1}\right)$ at st. 11 , which co-occurred with the highest levels of DA in MiP samples $\left(\sim 3500\right.$ and 5000 ng DA NT $\left.{ }^{-1}\right)$ (Fig. 2 A). In these samples, phytoplanktonic groups dominated with approximately $99 \%$ of the MiP total density whereas microzooplanktonic groups only contributed with a percentage of $\sim 1 \%$. Several heterotrophic - mixotrophic groups within microzooplankton were found at all the stations analyzed (Fig. 2 A). The main groups detected in the samples analyzed were in decreased order of occurrence, heterotrophic dinoflagellates (54\%), tintinnids (31\%), aloricate ciliates (2\%), foraminifera $(2 \%)$, and different crustacean larvae such as nauplii and copepodites of copepods (9\%). Heterotrophic dinoflagellates accounted for the highest density values at st. 5 (more than 30,000 cells $\mathrm{NT}^{-1}$ ) and the lowest values towards the southern stations. Tintinnids were the dominant group at stations $2,10 \mathrm{~A}, 11,12,13$, and 14 , while heterotrophic dinoflagellates were dominant at the rest of the stations.

Thirteen mesozooplanktonic groups were found to be widely distributed in the samples throughout the study area although only three of them (cladocerans, $N$. scintillans and small copepods) showed the highest mean density (Fig. 2 B, Table 1 Appendix A). Although N. scintillans is a dinoflagellate, it was quantified within mesozooplankton because by its big size, it was sampled in the 200 um mesh net. More than $50 \%$ of the overall MezooP groups were represented by crustaceans, mainly herbivores and omnivores. $N$. scintillans, cladocerans and small copepods ( $<1500 \mu \mathrm{m}$ total length), such as Paracalanus parvus, Euterpina acutifrons, Ctenocalanus vanus, and Oithona nana were -in decreasing orderthe most abundant taxa, followed by some invertebrate larvae and large copepods ( $>1500 \mu \mathrm{m}$ total length), such as Calanoides carinatus and Calanus australis. Total MezooP density reached the highest value at one station on the coast of VP (st. 13) where $N$. scintillans was the dominant species $(80 \%)$ followed by small copepods $(15 \%)$ and Calanidae nauplii (5\%). The second highest value was found quite northward (st. 12) where cladocerans accounted for more than $50 \%$ of total MezooP density followed by small copepods and invertebrate larvae (15\% each), and Calanidae nauplii plus the large-sized copepods from this family, such as C. carinatus and C. australis (10\%). A notorious increase in density of herbivorous and omnivorous taxa was observed towards the southern zone. The same trend was also registered in terms of biomass and scarce biomass values of carnivores were observed along the southern coasts of SMG and the eastern area of VP (Fig. 3).

\subsection{Domoic acid content in MiP and MezooP}

DA was detected in six MiP samples ( $40 \%$ of the total) from the southwestern coast of SMG and from the eastern coast of VP (Fig. 2 A). Whereas the minimum value was below $300 \mathrm{ng} \mathrm{NT}^{-1}$, the maximum value reached $5041 \mathrm{ng} \mathrm{NT}^{-1}$, the mean value being $783 \mathrm{ng} \mathrm{NT}^{-1}$ (Table 1, Supplementary Material). High levels of DA in MiP (ca. $4000 \mathrm{ng} \mathrm{NT}^{-1}$ and $3000 \mathrm{ng} \mathrm{NT}{ }^{-1}$ ) were also found at two other stations. DA was detected in nine MezooP samples (60\%) from the same zone, the highest values being close to $2000 \mathrm{ng} \mathrm{NT}^{-1}$ and $\sim 1500 \mathrm{ng}$ $\mathrm{NT}^{-1}$. DA in this fraction showed a similar spatial distribution pattern to that observed in MiP (Fig. $2 \mathrm{~B}$ ).

\subsection{Relationships between density of Pseudo-nitzschia spp., potential DA vectors}

Only all the significant correlation relationships found were listed in Table 2. Significant and positive Spearman correlations $(p<0.05)$ were detected between DA content in MiP and in MezooP and density of $P$. australis, $P$. pungens, and specimens of $P$. pseudodelicatissima complex (Table $2 \mathrm{~A}$ ). The density of the three above-mentioned species showed to be positive and significantly inter-correlated ( $P$. australis vs $P$. pungens: $\mathrm{r}_{\mathrm{s}} 0.68, P$. australis vs $P$. pseudodelicatissima c.: $\mathrm{r}_{\mathrm{s}} 0.89$ and $P$. pungens vs $P$. pseudodelicatissima c.: $\mathrm{r}_{\mathrm{s}} 0.81$ ). In spite of the occurrence of $P$. fraudulenta in the study area, its density was not significantly correlated with DA. Likewise, total microzooplankton density and the density of their groups were not significantly correlated with either DA MiP and DA MezooP or Pseudo-nitzschia species density (data not shown). In contrast, MezooP density and that of some groups or species were both significantly correlated with Pseudo-nitzschia spp. density, DA MiP and/or DA MezooP (Table 2 B). Calanidae nauplii density showed a high and significant correlation with $P$. australis, $P$. pungens, and the $P$. pseudodelicatissima complex density and with DA MiP and DA MezooP. In contrast, euphausiids and cladocerans were the only groups within MezooP associated with $P$. fraudulenta density. Furthermore, whereas total MezooP and small copepod densities were correlated with DA MezooP, small copepod density was positively correlated with DA MiP. In addition, while $O$. nana, $P$. parvus, $C$. vanus, and $C$. carinatus density showed a significant and positive correlation with DA MezooP, $O$. nana, $P$. parvus and C. carinatus also showed a positive correlation with DA MiP. O. nana was the only copepod that showed to be positively correlated with the density of $P$. australis, $P$. pungens, and $P$. pseudodelicatissima complex. Likewise, when the biomass data of mesozooplankton groups were correlated with DA MezooP and DA MiP, some of these taxa, such as Calanidae nauplii, $O$. nana, and the cladocerans $P$. polyphemoides and Evadne normanni, showed to be positively and significantly associated (Table $2 \mathrm{C}$ ). Significant positive correlations were also found between the data on copepod grazing rate (for $O$. nana and Calanidae nauplii) and DA in both plankton fractions.

As for the significant correlations with environmental variables (Table 3), P. australis, $P$. pungens and $P$. pseudodelicatissima complex 

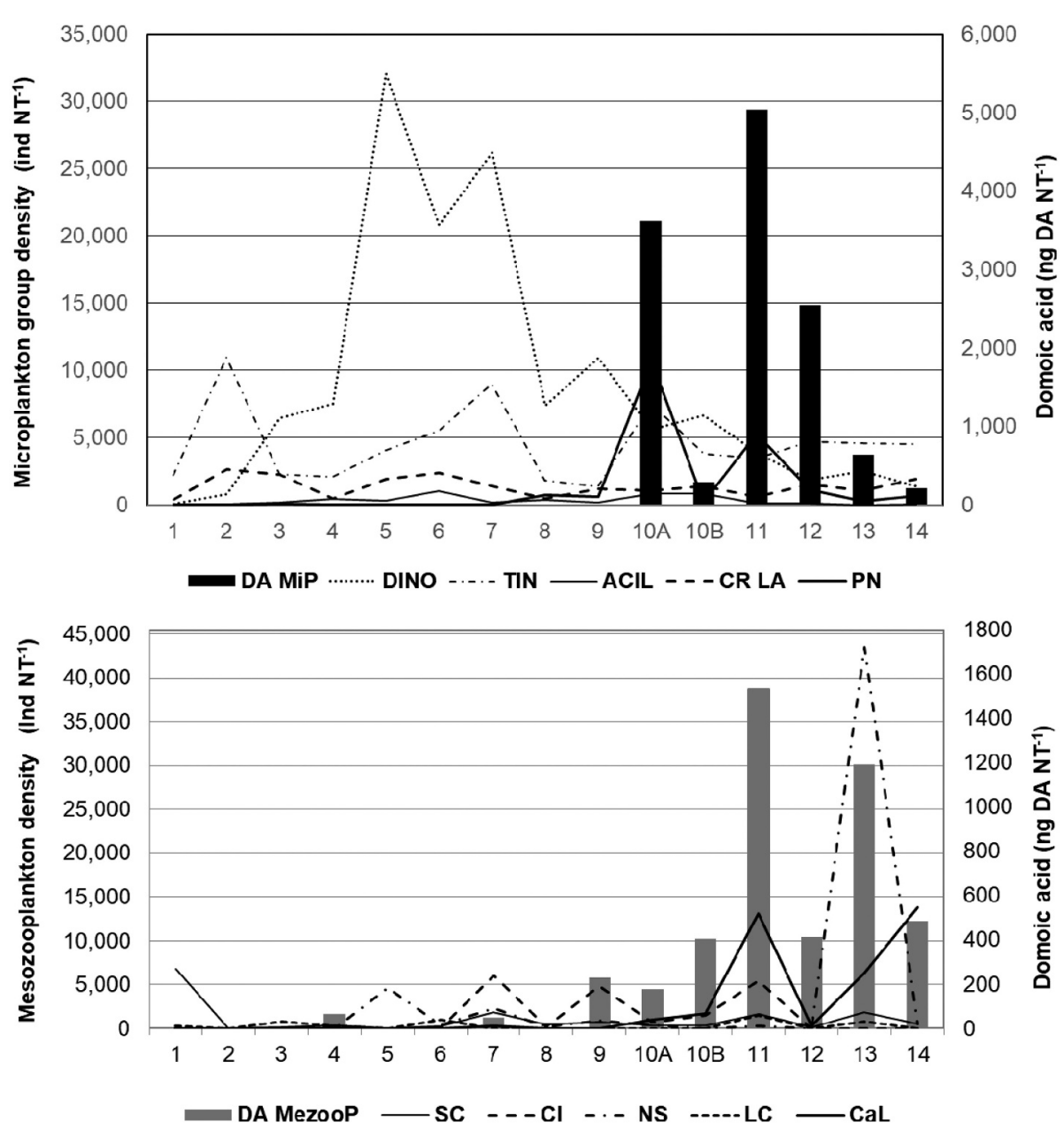

Fig. 2. Above, spatial distribution of Pseudo-nitzschia spp density, microzooplankton groups density values and domoic acid (DA) content values along the sampling stations. DA MiP = DA content in microplankton, $\mathrm{PN}=$ Pseudo-nitzschia spp. density, DINO = dinoflagellates, TIN $=$ tintinnids, $\mathrm{ACIL}=$ aloricate ciliates, $\mathrm{CL}=$ crustacean larvae. Below, spatial distribution of the density of mesozooplankton groups and DA content values along the sampling stations. DA MezooP = DA content in mesozooplankton. $\mathrm{SC}=$ small copepods, $\mathrm{CL}=$ cladocerans, $\mathrm{Ca} \mathrm{L}=$ Calanidae Larval stages (i.e. nauplii and copepodites) and $\mathrm{NS}=N$. scintillans. Sampling stations as mentioned in Table 1. densities showed a negative correlation coefficient with temperature but a positive correlation with nitrate. Total microzooplankton, heterotrophic dinoflagellate, and aloricate ciliate densities showed high and positive correlations with salinity. Tintinnids, in turn, were the only group that showed a negative correlation with Chl- $a$ concentration. Within MezooP, Calanidae nauplii density was negatively correlated with temperature and dissolved oxygen but positively correlated with nitrate. The density of the dinoflagellate $N$. scintillans only showed a negative correlation with phosphate. Small copepod species density was negatively correlated with temperature ( $O$. nana and $P$. parvus) and with dissolved oxygen (P. parvus and $E$. acutifrons). E. acutifrons also showed a positive correlation with nitrate. $O$. nana density was positively correlated with nitrate, while $C$. carinatus density was negatively correlated with both dissolved oxygen and Chl- $a$ concentration, but positively correlated with nitrate as well. DA MiP and DA MezooP were positively correlated with nitrate but negatively correlated with temperature, the former was also negatively correlated with both dissolved oxygen and Chl- $a$ concentration.

\subsection{Principal component analysis}

Results from PCA revealed the relationships of all the variables considered with the two first components and the location of samples on the plane (Fig. 4 A and B). PC I and PC II showed to accumulate $54.7 \%$ of the total variance explanation. PC 1 showed highly significant positive correlation coefficients with DA MiP and DA MezooP, density of Pseudo-nitzschia species, density of copepod species or stages (total copepods, E. acutifrons, O. nana, C. australis, Calanidae nauplii, and Calanidae copepodites), and nitrate and phosphate within the environmental variables, whereas it also showed a highly significant negative coefficient with temperature (Fig. 4 A). PC II showed to be linked through positively significant correlation coefficient values with the copepods $C$. carinatus, $C$. vanus and $P$. parvus and with silicic acid (Fig. 4 A). It was significantly negatively correlated with $P$. fraudulenta and the remaining environmental variables, such as dissolved oxygen, salinity, $\mathrm{pH}$, turbidity and chlorophyll-a.

The spatial location of each of the samples analyzed on the plane of the two first principal components, which are in agreement with the position of the variables on the plane, is shown in Fig. 4 B. It is closely related to the variables that explain either one or the other component of the PCA. The samples from the sampling stations $10 \mathrm{~A}$ to 14 were therefore related to the variables explaining PC I and the rest of samples were matched with PC II environmental variables.

\section{Discussion and conclusions}

\subsection{Oceanographic, environmental and biotic influence for bloom development}

The total density of toxigenic Pseudo-nitzschia spp. as well as the density of some of the mesozooplanktonic species analyzed in this study were strongly associated with high concentrations of nitrate and low temperatures. This is in agreement with results from previous studies which have indicated similar and favorable environmental conditions for Pseudo-nitzschia spp. blooms in upwelling and eutrophic zones (Trainer et al., 2012 and references therein; Almandoz et al., 2017). In SMG, monthly satellite Chl- $a$ and seasonal environmental data characterize the phytoplankton biomass cycle as typical of temperate waters (Williams et al., 2013). During summer, both field (Carreto and Verona, 1974; Carreto et al., 1974; Rivas and Beier, 1990; Williams, 2011) and 

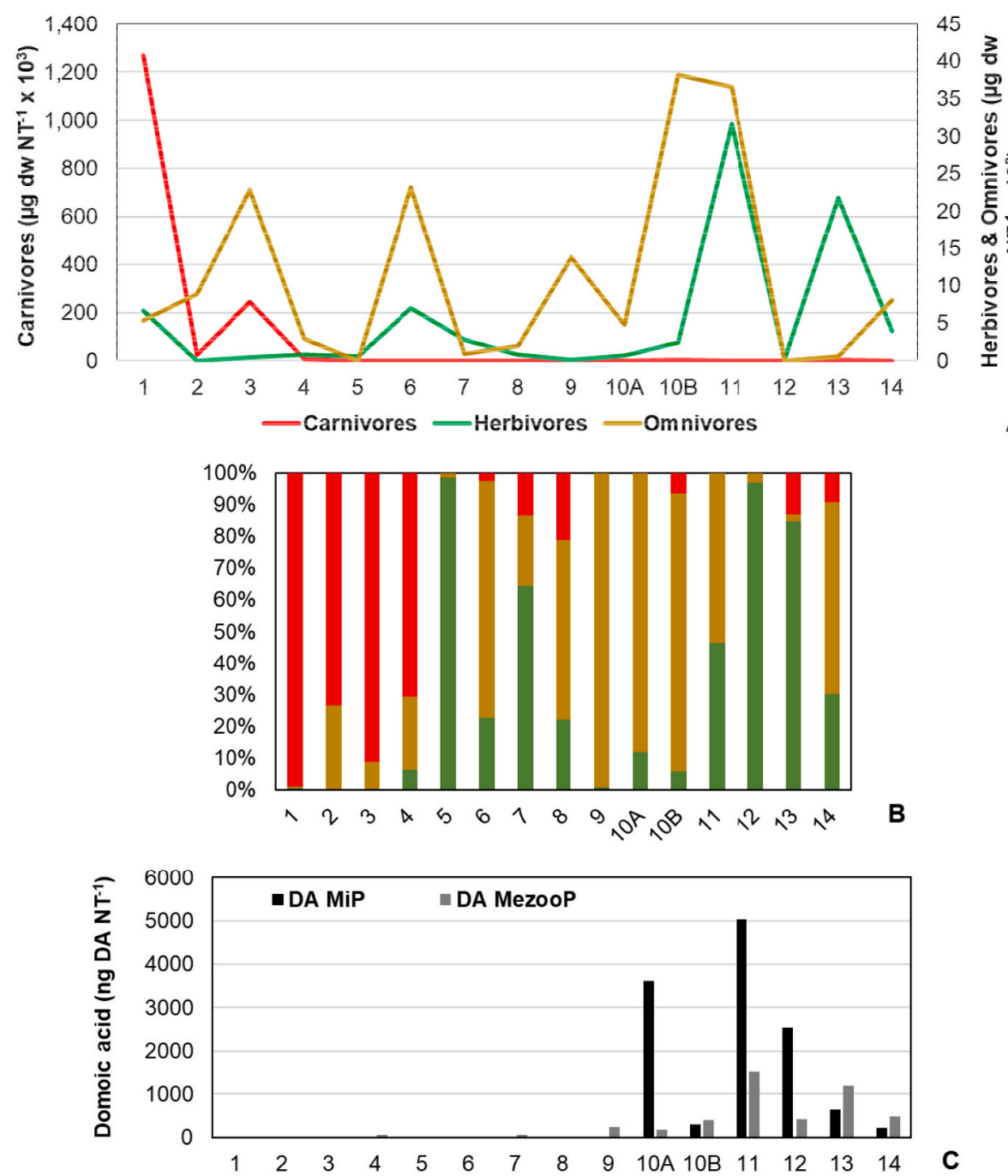

Fig. 3. Spatial pattern of biomass of herbivorous, omnivorous and carnivorous mesozooplanktonic groups along the study area. A - Absolute biomass values expressed in terms of dry weight. B - Relative biomass values expressed in percentage. C - DA content in microplankton (DA MiP) and mesozooplankton (DA MezooP) in black bars and dark gray bars, respectively.

satellite image data (Gagliardini and Rivas, 2004; Williams et al., 2013) show two well-differentiated zones based on their physical and chemical/biological characteristics, namely the southern zone with colder waters and usually high Chl- $a$ concentrations and the northern zone with warmer waters and low Chl- $a$ concentrations. In our study, this pattern was reflected in the data regarding temperature and nutrients but not in the data regarding Chl- $a$. The spatial distribution of plankton in SMG seems to be determined by a thermal front and by a water circulation pattern associated with this condition (Tonini et al., 2013; Pisoni et al., 2014).

Interestingly, in situ and satellite $\mathrm{Cl}-a$ data showed a phytoplankton bloom which was originally located on the northern zone of SMG and was observed to be spatially longer on March 19th reaching the western coast and extending eastwards. Nonetheless, maximum values of i) DA content in the two plankton fractions analyzed (MiP and MezooP), ii) Pseudo-nitzschia spp. density, and iii) density of the potential mesozooplanktonic consumers of Pseudo-nitzschia spp. were found only along the southern sampling stations and co-occurred with satellite and in situ low Chl- $a$ values (range $0.34-1.50$ for sts. 10 to 14 ). This clearly shows that the Chl- $a$ levels detected in our study are not specific for Pseudo- nitzschia spp. and that these levels depend on the general composition of phytoplankton. Although it has been observed that satellite images are a good reflection of the relative spatial and temporal distribution of in situ Chl- $a$ data in this area (Williams et al., 2013), it must be taken into account that the performance of MODIS algorithm could be affected by the size, shape, and physiological or trophic state of phytoplankton cells (Dogliotti et al., 2009).

Within MiP, the affinity of different microzooplanktonic groups with distinct environmental conditions did not make it possible to interpret our data on spatial variability in terms of a single pattern. None of these groups was significantly correlated with either density of Pseudo-nitzschia spp. or DA in MiP or DA in MezooP contents. In contrast, within MezooP, the density of small copepods (O. nana and $E$. acutifrons) and that of Calanidae nauplii showed significant negative correlations with temperature and significant positive correlations with nitrate. These relationships, which were similar to those found for DA in both plankton fractions and Pseudo-nitzschia spp., seem to explain why the highest density values of these mesozooplanktonic groups were also found all along the southeastern coasts of SMG and the eastern coast of VP. The high levels of nitrate in this zone (Williams, 2011) could be 
Table 2

Spearman's correlation coefficients obtained among all variables evaluated in this study (only significant values are shown). A - Coefficient values obtained between Pseudo-nitzschia spp. density (bottle samples data) taken from Almandoz et al. (2017) and DA contents in microplankton and mesozooplankton (DA MiP and DA MezooP) per net tow. $N=16$. B - Coefficient values obtained between total mesozooplankton density, density of the main mesozooplanktonic groups and density of particular species with Pseudo-nitzschia spp. density, DA MiP and DA MezooP. C - Coefficient values obtained between biomass of the main mesozooplanktonic groups and DA MiP and DA MezooP. D - Coefficient values between grazing rates estimated for copepod taxa and DA in MiP and in MezooP. $N=15$. Mesozooplankton sample for st. 16 was not available. (*) Nauplii belonging mainly to $C$. carinatus. c. complex.

\begin{tabular}{|c|c|c|c|}
\hline VARIABLES & & $\mathrm{r}_{\mathrm{s}}$ & $p$-value \\
\hline \multicolumn{4}{|l|}{ A } \\
\hline Pseudo-nitzschia australis & DA MiP & $0.89 * *$ & $2.81 \mathrm{E}-6$ \\
\hline P. pungens & DA MiP & $0.81 * *$ & 0.0001 \\
\hline P. pseudodelicatissima c. & DA MiP & $0.96 * *$ & $1.8 \mathrm{E}-9$ \\
\hline P. pseudodelicatissima c. & DA MeP & $0.64 * *$ & 0.0072 \\
\hline \multicolumn{4}{|l|}{ B } \\
\hline Calanidae nauplii (*) & P. australis & $0.83 * *$ & 0.0001 \\
\hline C. nauplii (*) & P. pungens & $0.66 * *$ & 0.0075 \\
\hline C. nauplii (*) & P. pseudodelicatissima c. & $0.9 * *$ & $3.62 \mathrm{E}-6$ \\
\hline C. nauplii (*) & DA MiP & $0.86 * *$ & $3.76 \mathrm{E}-5$ \\
\hline C. nauplii (*) & DA MezooP & $0.86 * *$ & $2.97 \mathrm{E}-5$ \\
\hline Euphausiids & P. fraudulenta & $0.56 *$ & 0.0290 \\
\hline Cladocerans & P. fraudulenta & $0.67 * *$ & 0.0060 \\
\hline Small copepods & DA MiP & $0.55 *$ & 0.0330 \\
\hline Small copepods & DA MezooP & $0.57 *$ & 0.0260 \\
\hline Total mesozooplankton & DA MezooP & $0.52 *$ & 0.0450 \\
\hline Oithona nana & P. australis & $0.64 * *$ & 0.0090 \\
\hline O. nana & P. pungens & $0.53 *$ & 0.0432 \\
\hline O. nana & P. pseudodelicatissima c. & $0.57 *$ & 0.0251 \\
\hline O. nana & DA MezooP & $0.74 * *$ & 0.0016 \\
\hline Euterpina acutifrons & DA MiP & $0.59 *$ & 0.0401 \\
\hline Paracalanus parvus & DA MezooP & $0.53 *$ & 0.0397 \\
\hline Ctenocalanus vanus & DA MezooP & $0.75 * *$ & 0.0076 \\
\hline Calanoides carinatus & DA MezooP & $0.52 *$ & 0.0481 \\
\hline \multicolumn{4}{|l|}{$\mathrm{C}$} \\
\hline O. nana & DA MeP & $0.68^{* *}$ & 0.0055 \\
\hline O. nana & DA MiP & $0.59^{*}$ & 0.0201 \\
\hline C. nauplii (*) & DA MezooP & $0.78 * * *$ & 0.0007 \\
\hline C. nauplii (*) & DA MiP & $0.86^{* * *}$ & 0.0000 \\
\hline Pleopis polyphemoides & DA MezooP & $0.61^{*}$ & 0.0165 \\
\hline Evadne nordmanni & DA MeP & $0.67 * *$ & 0.0063 \\
\hline \multicolumn{4}{|l|}{$\mathrm{D}$} \\
\hline O. nana & DA MezooP & $0.64 *$ & 0.0101 \\
\hline O. nana & DA MiP & $0.73^{* *}$ & 0.002 \\
\hline C. nauplii (*) & DA MezooP & $0.78^{* *}$ & 0.0006 \\
\hline C. nauplii (*) & DA MiP & $0.86^{* *}$ & $3.78 \mathrm{E}-5$ \\
\hline
\end{tabular}

attributed to the close location of Península Valdés tidal front and its seasonal dynamics (Acha et al., 2015; Paparazzo et al., 2010; Amoroso et al., 2010; Pisoni et al., 2015), the presence of a thermal front identified in SMG (Pisoni et al., 2015; Williams et al., 2010), and the probable occurrence of upwelling events resulting from the effect of strong winds on the seawater column as that reported for March 2008 by Pisoni et al. (2015). In addition, by using high resolution satellite images, Amoroso and Gagliardini (2010) observed eddies formed from jets that leave SJG and reach the center of SMG, which could be interpreted as a nutrient and living organism (larvae, spores) transportation mechanism between SJG and SMG.

In the Juan de Fuca region on the western coast of USA, significant and positive correlations between macronutrients and particulate DA were found to be the effect of a particular eddy (Trainer et al., 2009). Likewise, the oceanographic characteristics that typify the southern area
Table 3

Significant Spearman's rank correlation coefficients obtained among Pseudonitzschia species density, DA MiP and DA MezooP (domoic acid content in micro- and mesozooplankton) and density of mesozooplanktonic groups with environmental variables. $\mathrm{N}=15$. c. complex.

\begin{tabular}{llll}
\hline Variables & & $\mathrm{r}_{\mathrm{sp}}$ & Sign. \\
\hline P. australis & Temperature & $-0.81^{* *}$ & 0.0001 \\
P. australis & Nitrate & $0.77^{* *}$ & 0.0004 \\
P. pungens & Temperature & $-0.62^{*}$ & 0.0104 \\
P. pungens & Nitrate & $0.7 * *$ & 0.0023 \\
P. pseudodelicatissima c. & Temperature & $-0.77^{* *}$ & 0.0004 \\
P. pseudodelicatissima c. & Nitrate & $0.81^{* *}$ & 0.0001 \\
P. pseudodelicatissima c. & Dissolved oxygen & $-0.62 * *$ & 0.0099 \\
DA MiP & Temperature & $-0.78 * *$ & 0.0002 \\
DA MiP & Nitrate & $0.83 * *$ & $6.1 \mathrm{E}-5$ \\
DA MiP & Dissolved oxygen & $-0.53 *$ & 0.0326 \\
DA MiP & Chlorophyll- $a$ & $-0.56 *$ & 0.0290 \\
DA MezooP & Temperature & $-0.64 * *$ & 0.0098 \\
DA MezooP & Nitrate & $0.8 * *$ & 0.0003 \\
Calanidae nauplii & Temperature & $-0.65 * *$ & 0.0083 \\
C. nauplii & Dissolved oxygen & $-0.63 *$ & 0.0110 \\
C. nauplii & Nitrate & $0.74 * *$ & 0.0014 \\
N. scintillans & Phosphate & $-0.51 *$ & 0.0480 \\
O. nana & Temperature & $-0.53 *$ & 0.0412 \\
O. nana & Nitrate & $0.55 *$ & 0.0325 \\
$P$. parvus & Temperature & $-0.52 *$ & 0.0468 \\
P. parvus & Dissolved oxygen & $-0.52 *$ & 0.0440 \\
E. acutifrons & Dissolved oxygen & $-0.56 *$ & 0.0296 \\
E. acutifrons & Nitrate & $0.54 *$ & 0.0382 \\
C. carinatus & Dissolved oxygen & $-0.58 *$ & 0.0216 \\
C. carinatus & Chlorophyll- $a$ & $-0.59 *$ & 0.0200 \\
C. carinatus & Nitrate & $0.54 *$ & 0.0382 \\
\hline & & & \\
\hline & & &
\end{tabular}

of SMG and Península Valdés tidal front (Sabatini and Martos, 2002; Piola et al., 2018) could favor the development of toxigenic Pseudonitzschia spp. blooms. Trainer et al. (2000; 2002) reported high Pseudonitzschia species density and high DA content on the western coast of USA and observed that both facts were associated with high salinity, low temperature, and high nutrient concentrations (mainly nitrates), all of which are typical of upwelling areas. Similar conditions, although with lower salinity values, seem to have promoted the peaks of Pseudo-nitzschia spp. observed in our study. Unusual oceanographic events can also be precursors of Pseudo-nitzschia blooms. For example, in late spring of 2015, an extreme and massive HAB of Pseudo-nitzschia australis was recorded in the western coastal region of USA (Trainer et al., 2019) which was related to a previous oceanographic phenomenon called "the Blob" (McCabe et al., 2016; McKibben et al., 2017; Trainer et al., 2019). The latter was an extraordinary and persistent heatwave with warm SST condition $\left(\sim 3^{\circ} \mathrm{C}\right)$ which mimicked climate change condition events during the years 2013, 2014 and 2015 over the western coast of USA from Alaska and British Columbia to the California region along the California Current System (CCS) (Trainer et al., 2019). The role that is attributed to "the Blob" was that of maintaining viable toxigenic Pseudonitzschia cells in the poor-nutrient and warm waters of these areas and then transporting them into the coast. Once in the shelf waters, particularly when waters from "the Blob" mixed with cool upwelling waters, macronutrients quickly fueled the Pseudo-nitzschia australis bloom development and the posterior intense DA outbreak with harmful consequences for coastal fisheries (Trainer et al., 2019).

Both the development of Pseudo-nitzschia spp. blooms as well as DA production by toxigenic species have been associated worldwide with effects derived from interacting factors, such as macronutrient concentrations (generally low values of silicic acid and phosphate and high nitrate or ammonia), high concentrations of micronutrients, such as iron and copper, differences in $\mathrm{pH}$, bacteriae and effects of predator 

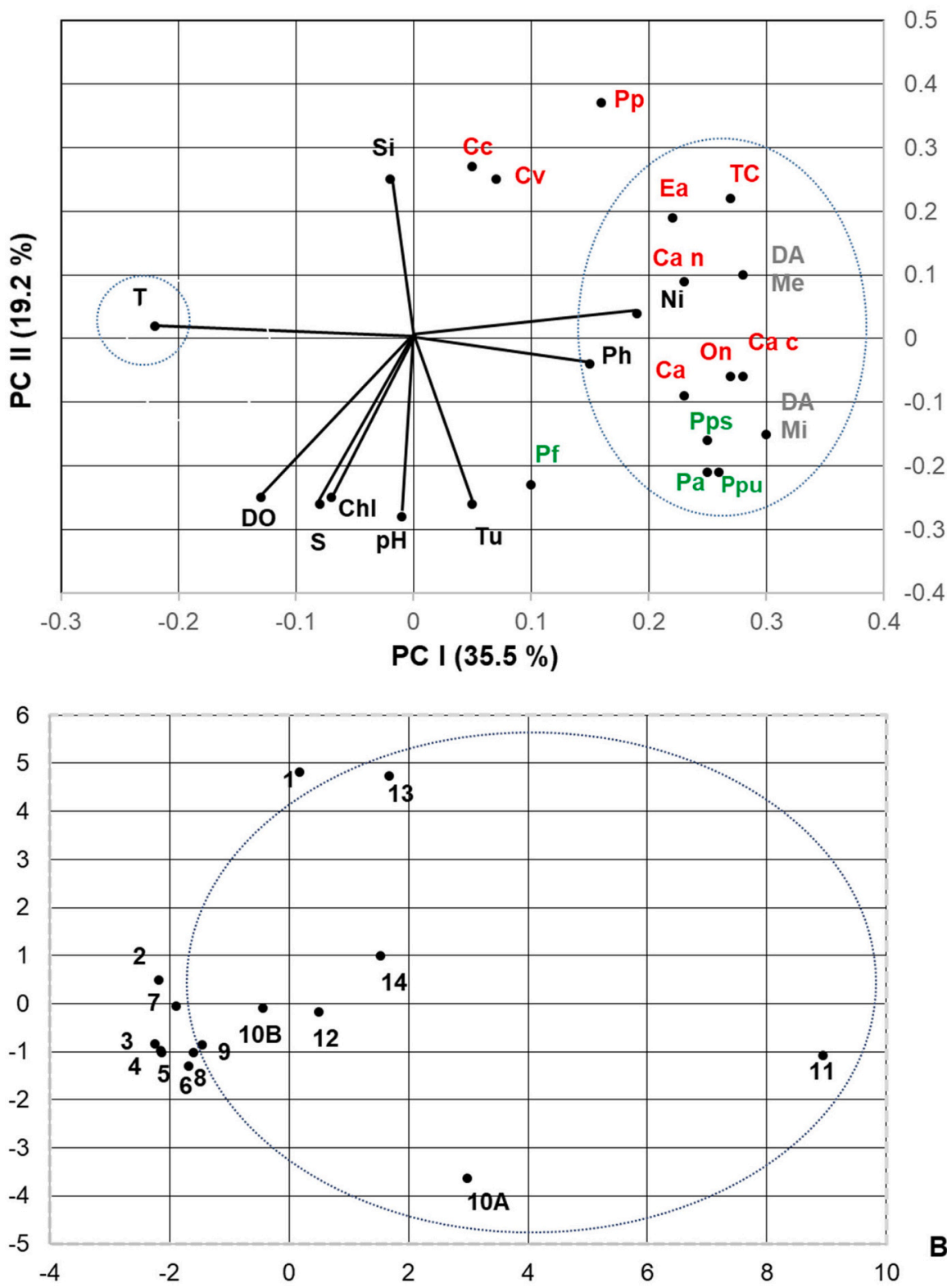

Fig. 4. Results of the PCA performed with copepod groups and species, Pseudo-nitzchia spp. density, DA MiP, DA MezooP and nine environmental variables. A - Graph of the two first principal components (PC I and PC II). Nine environmental variables and axes in black color. Temperature (T), silicic acid (Si), nitrate (Ni), phosphate (Ph), turbidity (Tu), Hydrogen potential (pH), chlorophyll- $a(\mathrm{Chl})$, salinity (S) and dissolved Oxygen (DO). In terms of density and in red color: total copepods (TC), Calanidae nauplii (Ca $\mathrm{n}$ ), Calanidae copepodites (Ca c), Calanus australis (Ca), C. carinatus (Cc), Ctenocalanus vanus (Cv), Paracalanus parvus (Pp), Euterpina acutifrons (Ea), Oithona nana (On). In terms of density and in green color: Pseudo-nitzschia australis $(\mathrm{Pa}), \quad P$. pungens (Ppu), P. pseudodelicatissima complex (Pps), P. fraudulenta (Pf) and finally, DA content in MiP and DA MezooP (as DA Mi and DA Me in this graphic) in dark gray color. The areas inside two dark blue ovals indicate the variables strongly correlated with the first principal component (PC I) and the bloom. The rest of the variables that are out of the dark blue ovals strongly correlated with the second principal component. B - The position of the sampling stations was graphed according to the factor scores for cases of the PCA. chemical cues, such as copepodamides (Windurst, 1992; Maldonado et al., 2002; Fehling et al., 2004; Lundholm et al., 2004; Marchetti et al., 2004; Schnetzer et al., 2007; Marchetti et al., 2008; Trainer et al., 2009, 2012; Tammilehto et al., 2012, 2015; Harðardóttir et al., 2015; Lundholm and Harðardóttir, 2017; Lundholm et al., 2018; Grebner et al., 2019; Selander et al., 2019). Nonetheless, the interaction of these multiple factors makes it difficult to predict the occurrence of toxic Pseudo-nitzschia spp. blooms (Tammilehto et al., 2015). The environmental characteristics observed in this study, namely low concentration of silicic acid, high N:Si ratio, high nitrate concentrations, low temperature and peaks of Pseudo-nitzschia spp. density appear to indicate favorable macronutrient conditions for bloom development. Recurrent blooms of Pseudo-nitzschia spp. have been reported in the Argentine Sea, mainly on the coasts of Buenos Aires Province, northern Patagonian gulfs and the Beagle Channel (Negri et al., 2004; Sastre et al., 2007; Cadaillón, 2012; Almandoz et al., 2007, 2011, 2017). In agreement with results from previous research, it was observed that DA-producing species peaks occur frequently under low temperature, relatively high nitrate concentrations, and high MezooP density conditions (Cadaillón, 2012; D'Agostino et al., 2017) while the decrease in bloom density appears to be partially linked to top-down control exerted by MezooP grazers consuming Pseudo-nitzschia cells (Turner et al., 2014).

Previous studies conducted under experimental conditions have demonstrated that high concentrations of chemical substances synthesized by copepods, called copepodamides, induce the production of DA by Pseudo-nitzschia spp. (Harðardóttir et al., 2015; Selander et al., 2015; Lundholm and Harðardóttir, 2017; Lundholm et al., 2018; Grebner et al., 2019; Selander et al., 2019). Tammilehto et al. (2015) experimentally demonstrated that large Calanidae copepods (Calanus hyperboreous and C. finmarchicus) induce DA production (up to 130 times) by Pseudonitzschia seriata and also suggested that zooplankton grazing is one of the factors that controls the toxicity of Pseudo-nitzschia spp. blooms in the field. Harðardóttir et al. (2015) and Lundholm et al. (2018) corroborated this hypothesis according to which copepodamides from copepodites of 
Calanus spp. and other copepod species induce DA production which represents a defense mechanism at least for $P$. seriata and $P$. obtusa. Taking into account the high density of copepods (mainly herbivores and omnivores) observed in the present study across the southern stations in SMG, the high concentrations of copepodamides could be partly responsible for inducing DA production in Pseudo-nitzschia spp., giving rise to the elevated DA contents observed in the samples from this zone.

\subsection{Density of Pseudo-nitzschia spp. and DA content in MiP and MezooP}

The spatial pattern of DA content in MezooP recorded in this study showed that the maximum density values occurred in the southern sector of SMG and eastern coasts of VP. This pattern was similar to that of DA MiP and therefore agrees well with the highest Pseudo-nitzschia spp. density values previously reported in this zone by Almandoz et al. (2017) from samples of the same expedition. These authors reported four Pseudo-nitzschia spp. species in bottle and net MiP samples which were identified as $P$. australis, $P$. pungens, $P$. fraudulenta, and specimens of the $P$. pseudodelicatissima (Hasle) Hasle species complex sensu Lundholm et al. (2003). Almandoz et al. (2017) also showed a Pseudonitzschia spp. density average of 3,000 cells. $\mathrm{L}^{-1}$ (maximum values of up to $6.5 \times 10^{4}$ cells. $\mathrm{L}^{-1}$ ) which represented between $\approx 0.5$ to $50 \%$ of the total diatom density in bottle samples. Therefore, taking into account the density of each species of Pseudo-nitzschia spp. (in Almandoz et al., 2017), DA content in MiP net samples was clearly due to DA content in the cells mainly from $P$. australis, a species that is considered highly toxigenic (Lelong et al., 2012), and -to a lesser extent- from cells of $P$. pungens which is comparatively considered a less toxic species. As to $P$. pseudodelicatissima, which is not considered toxigenic (Lelong et al., 2012; Almandoz et al., 2017), it was observed that it showed high significant correlations with DA in MiP and Da in MezooP, thus suggesting co-occurrence of DA rather than contribution of DA produced by this species. The maximum density of Pseudo-nitzschia spp. in net samples was observed to reach bloom values of up to $10,700 \times 10^{6}$ cells $\mathrm{NT}^{-1}$ whereas microzooplankton groups only contributed with approximately $1 \%$ to total microplankton. This percentage therefore indicates that, undoubtedly, DA contributors in microplankton were primarily toxigenic Pseudo-nitzschia spp. cells, mainly from $P$. australis, which was confirmed by the high significant correlation coefficient obtained between both variables. Interestingly, in our study, the maximum values of Pseudo-nitzschia spp. density were found to co-occur with the highest values of MezooP density $(\sim 2000 \mathrm{ng}$ $\mathrm{NT}^{-1}$ ). In addition, the high correlations found between Pseudo-nitzschia spp. density and DA MezooP as well as those between the density of some potential DA consumers and DA MiP confirm that DA transfer and accumulation processes occurred through consumers that are at the same time DA vectors. The absence of Pseudo-nitzschia spp. frustules in the mesozooplankton samples, which was confirmed after a careful light microscopic analysis, leads us to assert that DA MezooP only represented the DA accumulation in the body itself of Pseudo-nitzschia consumers and potential vectors.

Both DA production and DA ingestion-transfer-accumulation processes seem to have co-occurred in the study area with a partial overlapping but under favorable environmental conditions. The prevalence of either one or other of these processes seems to have depended on i) the contribution of a high density of toxigenic Pseudo-nitzschia spp. to DA content in MiP and the contribution of a high density of potential DA vectors to DA content in MezooP, ii) the capacity of different species of Pseudo-nitzschia spp. to produce DA in situ, and iii) the ability of vectors to reduce their density by consumption (Trainer et al., 2012 and references therein; Turner, 2014). To these hypotheses, we should add the effects of copepodamides, which are chemical cues emitted by copepods occurring in the HAB area or accumulated in water, which induce DA production in Pseudo-nitzschia spp. (Grebner et al., 2019; Selander et al., 2019). These authors have demonstrated, through doseresponse experiments, not only this effect on Pseudo-nitzschia seriata but also other defense traits, such as toxin production and bioluminiscence in the dinoflagellate Alexandrum minutun and chain shortening (colony reducing) in Skeletonema marinoi.

In addition, our results are sustained by those obtained by Cadaillón (2012) and D'Agostino et al. (2015, 2016, 2017, 2018, 2019) who reported not only DA transfer from Pseudo-nitzschia spp. to MezooP consumers in Nuevo Gulf (NG) and SJG during spring blooms but also cooccurrence of DA producers and potential mesozooplanktonic consumers. In line with this, Cadaillón (2012) found for the first time, DA content in microplankton (up to $40.96 \mu \mathrm{g} \mathrm{DA}^{-1}$ cells) in NG and in zooplankton (up to $42.78 \mu \mathrm{g} \mathrm{DA} \mathrm{g}^{-1}$ tissue) in SJG, both being values that, in the case of mollusks, are above the level permitted for human consumption. Although our study was carried out in austral late summer and in an area located close to these gulfs but outside them, we found a set of Pseudo-nitzschia spp. (without $P$. calliantha) similar to that observed by D'Agostino et al. (2017, 2018, 2019) and Cadaillón (2012) in the northern Patagonian gulfs during austral winter and spring. The presence of DA was detected in microplankton (up to $6139 \mathrm{ng} \mathrm{NT}^{-1}$ ) and in mesozooplankton (up to $11 \mathrm{ng} \mathrm{DA} \mathrm{NT}^{-1}$ ) during a bloom of Pseudo-nitzschia spp. in NG on September 10th 2015 and in feces of Eubalaena australis (D'Agostino et al., 2015, 2016, 2017). Remains of Pseudo-nitzschia spp. frustules were also documented in whale feces. The values reported for DA MezooP by these authors appear to be much lower than those recorded in our study in terms of ng per net tow (max. $2000 \mathrm{ng} \mathrm{NT}^{-1}$ ), thus suggesting that whereas DA production by Pseudonitzschia spp. was predominant during the bloom reported by D'Agostino et al. (2018, 2019) in NG in spring, in our study DA production as well as DA transfer and accumulation co-occurred in late summer. These findings are therefore indicative of the high risk to which primary and secondary consumers, right whales, and other marine animals are exposed as a result of the presence of DA in these northern Patagonian gulfs (D'Agostino et al., 2018, 2019). P. australis, $P$. fraudulenta, and $P$. pungens, which were reported to be toxigenic (Lelong et al., 2012), occur in the northern Patagonian gulfs and in our study region regardless of the season, thus indicating the potential risk of Pseudo-nitzschia spp. blooms and ASP outbreaks. On the other hand, although in our study $P$. fraudulenta was found not to be significantly correlated with DA in MiP nor with Pseudo-nitzschia spp. density, according to previous observations in the coastal waters of Chubut province (Sastre et al., 2007), it could become toxigenic under other environmental conditions. In view of the above, it is possible to conclude that the southern coasts of SMG and the eastern coast of VP show a great potential to develop Pseudo-nitzschia spp. blooms and DA toxic events in late summer.

\subsection{Density of microzooplankton and MezooP and DA potential vectors}

Microzooplankton and MezooP densities showed two different spatial patterns in the study area. Microzooplankton density was irregularly distributed throughout the region, the highest density values were found in the middle sector of SMG (sts. 5-7). A low density of phytoplankton (in terms of in situ Chl- $a$ ) and microzooplankton was detected in the southern area of SMG, thus suggesting MezooP topdown control (Turner et al. 2014) as well as the effect of a low concentration of silicic acid.

In contrast, the MezooP density pattern was consistently associated 
with the highest values of DA content in MiP and MezooP and of Pseudonitzschia spp. density, showing maximum values in the southern area of SMG. It is known that copepods and other MezooP metazoan groups prey on phytoplankton and microzooplankton, thus modifying the structure and dynamics of these communities (Hansson et al., 2005; Finenko et al., 2006; Garcia et al., 2015). DA transfer from toxigenic Pseudo-nitzschia spp. to MezooP consumers and its accumulation result from predatorprey interactions as shown through grazing and food selectivity experiments (Lincoln et al., 2001; Maneiro et al., 2005; Leandro et al., 2010 a, b; Turner, 2014 and references therein). The DA variability observed in $\mathrm{MiP}$ and MezooP net samples during the present study is likely indicative of these interactions. Nevertheless, the higher values of DA content in $\mathrm{MiP}$ with respect to those in MezooP at the stations located in the same zone (southern sector of SMG, st. 10A to 12) seem to indicate that in these sites DA production is higher than its accumulation and transfer, which could be a consequence of the high densities of toxigenic Pseudonitzschia species cells and the low ability of consumers to reduce their number. In contrast, in the most southern sampling stations (sts. 13 and 14), the content of DA MezooP was observed to be higher than the DA MiP produced, thus clearly suggesting that vector accumulation exceeded DA production by Pseudo-nitzschia spp.

The absence of significant correlations between microzooplankton density and DA MiP, DA MezooP and Pseudo-nitzschia spp. density as well as the highly significant positive correlations among the abovementioned variables and MezooP density strongly suggest that DA transfer occurs mostly through metazoan groups (mainly copepods) and the large dinoflagellate $N$. scintillans. Olson et al. (2008) attributed a secondary role as DA vectors to micro-heterotrophs. Nevertheless, in experimental studies, dinoflagellates, such as species of the genus $G y$ rodinium, have also been referred to as DA vectors (Buck et al., 2005). These micrograzers could therefore be considered another path for DA vectorization, i.e. toxins could pass through them to be consumed by omnivore mesozooplanktonic grazers and to be further accumulated. $N$. scintillans has, instead, the capacity to ingest small dinoflagellates, copepod eggs, copepod larvae, and even Pseudo-nitzschia spp. cells (Escalera et al., 2005; Sato et al., 2004; Fabro et al., 2015). The presence of high densities of this species recorded in the southern stations during our study and the shreds of evidence collected in this respect, leads to the conclusion that $N$. scintillans can be recognized as another DA vector.

The significant bivariate correlations found between density/biomass/grazing rate of small copepods (O. nana, E. acutifrons, $P$. parvus), Calanidae nauplii (mainly belonging to $C$. carinatus) and cladocerans $(P$. polyphemoides and E. nordmanni), with DA MezooP, DA MiP, or Pseudonitzschia spp. density and the same environmental conditions lead us to infer that the above-mentioned consumers are potential DA vectors transferring DA up in the pelagic food web. Another interesting element in support of this hypothesis is the co-occurrence of maximal values of both DA producers and these DA potential consumers on the southern coast of SMG and eastern coast of VP. The PCA results also contributed to support this inference. Briefly, in the PCA ordination, the density of mesozooplankton groups and species, such as total copepods, Calanidae nauplii, Calanidae copepodites, $O$. nana and $E$. acutifrons, the density of DA-producing species (Pseudo-nitzschia australis, P. pungens and $P$. pseudodelicatissima) and some environmental variables, such as nitrate, phosphate and temperature, explained PC I. In contrast, the density of other mesozooplankton groups and species, $P$. fraudulenta density and the rest of the environmental variables explained PC II. This leads us to conclude that whereas PC I seems to represent the Pseudo-nitzschia spp. $\mathrm{HAB}$ condition observed all along the stations of the southern zone (i.e., sts. 9-14), PC II seems to represent the non-HAB condition at the stations of the northern remaining zone in our study area. Within the potential vectors that highly correlated with PC I were Calanidae nauplii and $O$. nana. However, taking particularly into account $O$. nana feeding behavior, it seems unlikely that this small copepod can consume the large Pseudo-nitzschia spp. cells. So, further research is needed to elucidate the role of this species as well as that of the two cladoceran species observed and which were suggested to be DA vectors. Interestingly, it was possible to confirm a trend of increase in herbivore and omnivore biomass towards the southern stations. This trend was similar to that observed in terms of density (Fig. 3) which is in agreement with findings from Lundholm et al. (2018) under laboratory conditions: highest DA production was registered only for a major density of herbivore copepods. This finding appears to explain the reason why DA transfer was higher through an increased Pseudo-nitzschia spp. consumption.

All in all, our inferences are in agreement with findings from experimental research on DA ingestion and accumulation in diverse copepod species and copepodites of the genus Calanus (C. glacialis, C. finmarchicus, C. hyperboreous) as well as Temora longicornis, A. tonsa, A. clausi, and $N$. scintillans, all of which have been postulated to be potential vectors of DA (Lincoln et al., 2001; Tester et al., 2001; Maneiro et al., 2005; Escalera et al., 2007; Leandro et al., 2010b; Tammilehto et al., 2012, 2015; Harðardottir et al., 2015; Miesner et al., 2016). Our findings also suggest for the first time that novel taxa, such as Calanidae nauplii, as well as small-sized copepods, such as O. nana, E. acutifrons and $P$. parvus, and cladocerans, can have a role as DA vectors in the pelagic food web of the northern Patagonian coasts. Finally, in view of the relatively scarce data on DA in zooplankton compared to the literature available on DA in diatoms and microplankton, and taking into account the potential ecological effects of DA on coastal pelagic and benthic food webs in our study area, further field and experimental studies are mandatory not only to confirm the influence of the physicochemical and oceanographic conditions that favor Pseudo-nitzschia spp. peaks and DA accumulation in food webs but also to obtain direct evidence of Pseudo-nitzschia spp. consumption and accumulation by the mesozooplanktonic vectors responsible for DA transfer.

\section{Declaration of Competing Interest}

None.

\section{Acknowledgements}

We thank Sebastian Göller (AWI) and Facundo Barrera (IADO, CONICET-UNS) for plankton sampling and sample processing during the cruise, and Wolfgang Drebing (AWI) for sample extraction and toxin measurements by LC-MS/MS. We also thank the $2013 \mathrm{crew}$ of the $R / V$ Bernardo Houssay (Campaign 11th to 23th March, Prefectura Naval Argentina). This study was supported by ANPCYT, MINCYT (Argentina) grant (PICT2014-3091), IMCONet (FP7 IRSES, Action No. 319718), Marie Curie Actions within the Seventh Framework Programme (FP7) of the European Union and the Alfred-Wegener Institut, Helmholtz Zentrum für Polar- und Meeresforschung through the PACES research program of the Helmholtz-Gemeinschaft Deutscher Forschungszentren. Thanks are also due to Walter Melo (IADO) for his help in drawing figures and to Viviana Soler for her help in the language checking and improvement. The Authors thank very much the three reviewers of this article for their comments and advices. 


\section{Appendix A}
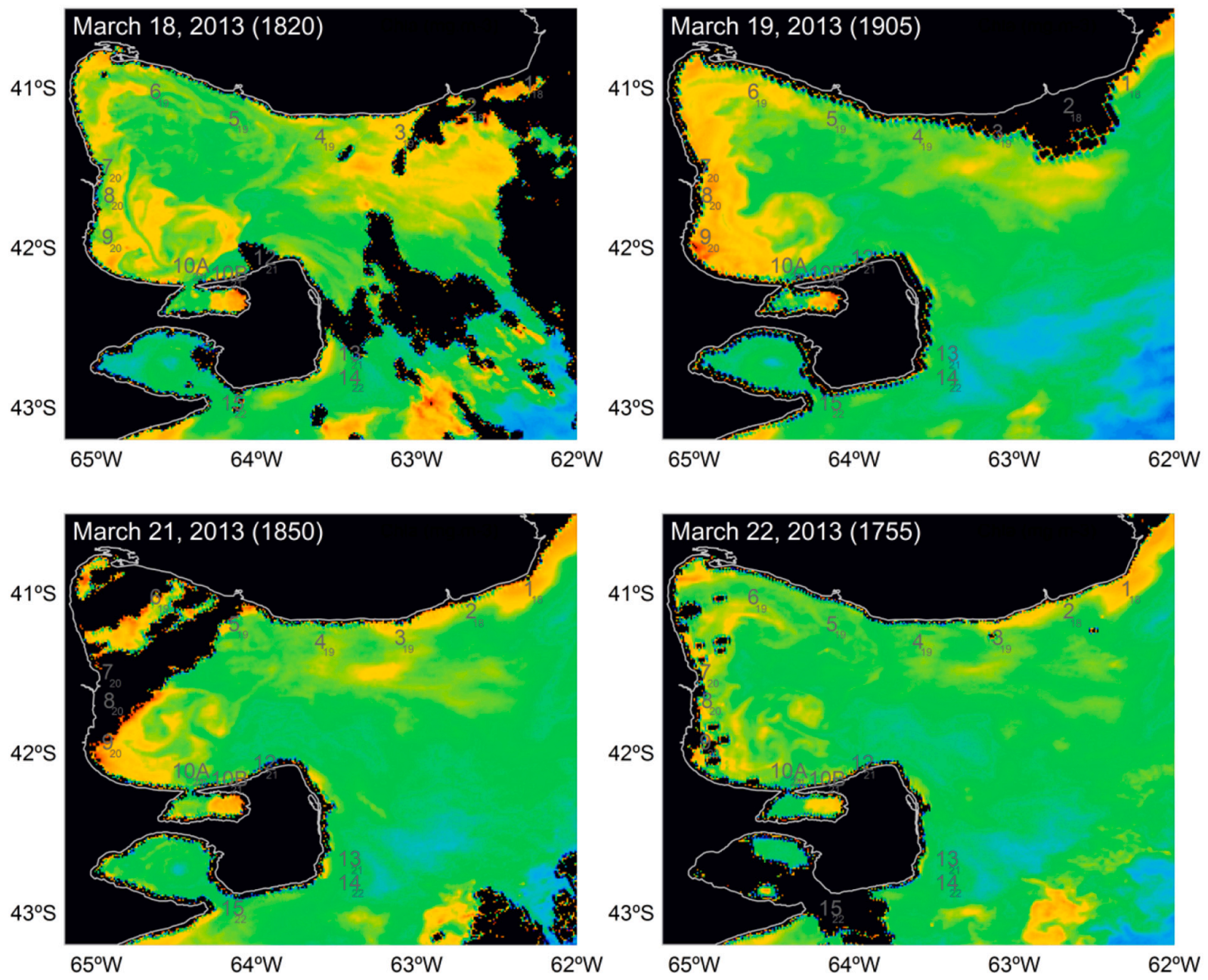

\begin{tabular}{llllllcl|}
\hline & & & & \multicolumn{3}{c|}{ Chla (mg.m-3) } \\
0 & 1 & 2 & 3 & 4 & 5 & 6 & 7
\end{tabular}

Fig. A.1. Surface chlorophyll- $a$ (Chl-a) maps (Aqua-MODIS - March 2013. Days: 18, 19, 21 and 22) as obtained from NASA Goddard Space Flight Center, Ocean Ecology Laboratory, Ocean Biology Processing Group. Moderate-resolution Imaging Spectroradiometer (MODIS) Aqua Ocean Color Data; 2013 Reprocessing. NASA OB. DAAC, Greenbelt, MD, USA. doi: https://doi.org/10.5067/AQUA/MODIS OC.2013.0 (Accessed on 15/10/2014). Numbers indicate the stations and subscript numerals indicate field sampling date. (For interpretation of the references to color in this figure legend, the reader is referred to the web version of this article.)

\section{References}

Skalar Analytical ${ }^{\circledR}$, V.B, 2005a. Skalar Methods c. Analysis: Silicate -Cat. Nr. 563-051 + DIAMOND issue 081505/MH/99235956. Breda (The Netherlands). Skalar Analytical ${ }^{\oplus}$, V.B, 2005b. Skalar Methods, a. Analysis: Nitrate + Nitrite - Cat. Nr. 461-031 + DIAMOND issue 081505/MH/99235956. Breda (The Netherlands).

Skalar Analytical ${ }^{\oplus}$, V.B, 2005c. Skalar Methods, b. Analysis: Phosphate - Cat. Nr. 503010w/r+DIAMOND issue 081505/MH/99235956. Breda (The Netherlands).

Williams, G.N., 2011. Caracterización ambiental del Golfo San Matías mediante sensores remotos y parámetros oceanográficos. In: Relación con la distribución y abundancia de los recursos biológicos de interés pesquero. Universidad Nacional del Comahue, San Carlos de Bariloche, Argentina PhD Thesis.

Acha, E.M., Piola, A., Iribarne, O., Mianzan, H., 2015. Ecological Processes at Marine Fronts, Oases in the Ocean. Springer, Berlin, Germany.

Almandoz, G.O., Ferrario, M.E., Ferreyra, G.A., Schloss, I.R., Esteves, J.L., Paparazzo, F.E., 2007. The genus Pseudo-nitzschia (Bacillariophyceae) in continental shelf waters of Argentina (Southwestern Atlantic Ocean, 38-55 S). Harmful Algae 6, 93-103.

Almandoz, G.O., Hernando, M., Ferreyra, G.A., Schloss, I.R., Ferrario, M.E., 2011. Seasonal phytoplankton dynamics in extreme southern South America (Beagle Channel, Argentina). J. Sea Res. 66, 47-57.

Almandoz, G.O., Fabro, E., Ferrario, M., Tillmann, U., Cembella, A., Krock, B., 2017.
Species occurrence of the potentially toxigenic diatom genus Pseudo-nitzschia and the associated neurotoxin domoic acid in the Argentine Sea. Harmful Algae 63, 45-55. Amoroso, R.O., Gagliardini, D.A., 2010. Inferring complex hydrographic processes using remote-sensed images: turbulent fluxes in the Patagonian gulfs and implications for scallop Metapopulation dynamics. J. Coast. Res. 26, 320-332.

Amoroso, R.O., Parma, A.M., Orensanz, J.M., Gagliardini, D.A., 2010. Zooming the macroscope: medium-resolution remote sensing as a framework for the assessment of a small-scale fishery. ICES J. Mar. Sci. 68, 696-706. https://doi.org/10.1093/ icesjms/fsq162.

Ara, K., 2001. Length-weight relationships and chemical content of the planktonic copepods in the Cananéia lagoon estuarine system, Sao Paulo, Brazil. Plank. Biol. Ecol. 48, 121-127.

Bargu, S., Marinovic, B., Mansergh, S., Silver, M., 2003. Feeding responses of krill to the toxin-producing diatom Pseudo-nitzschia. J. Exp. Mar. Biol. Ecol. 284, 87-104.

Bates, S.S., Trainer, V.L., 2006. The ecology of harmful diatoms. In: Granéli, E., Turner, J.T. (Eds.), Ecology of Harmful Algae. Springer-Verlag, Berlin, Germany, pp. 81-88. Bates, S.S., Hubbard, K.A., Lundholm, N., Montresor, M., Leaw, C.P., 2018. Pseudonitzschia, Nitzschia, and domoic acid: new research since 2011. Harmful Algae 79, $3-43$.

Boltovskoy, D., 1981. Atlas del zooplancton del Atlántico Sudoccidental y métodos de trabajo con el zooplancton marino. In: Instituto Nacional de Investigación y Desarrollo Pesquero. Publicación Especial, Mar del Plata, Argentina. 
Boltovskoy, D. (Ed.), 1999. South Atlantic Zooplankton. Vol I and II. Backhuys Publishers, Leiden.

Copepoda. In: Bradford-Grieve, J.M., Markhaseva, E.L., Rocha, C.E.F., Abichi, B. Boltovskoy, D. (Eds.), 1999. South Atlantic Zooplankton. Backhuys Publishers, Leiden, The Netherlands, pp. 869-1098.

Buck, K.R., Marin, I.I.I.R., Chavez, F.P., 2005. Heterotrophic dinoflagellate fecal pellet production: grazing of large, chain-forming diatoms during upwelling events in Monterey Bay, California. Aquat. Microb. Ecol. 40, 293-298.

Burns, J.M., Ferry, J.L., 2007. Adsorption of domoic acid to marine sediments and clays. J. Environ. Monit. 9, 1373-1377.

Cadaillón, A.M., 2012. Floraciones algales nocivas y ficotoxinas en fitoplancton y zooplancton de los golfos Nuevo y San José. Universidad Nacional de la Patagonia San Juan Bosco, Argentina, Lic. Thesis.

Carreto, J.I., Verona, C.A., 1974. Fitoplancton, pigmentos y condiciones ecológicas del Golfo San Matías: I, marzo de 1971. Anales Informes Comisión de Investigaciones Científicas Provincia de Buenos Aires (La Plata) 1-20.

Carreto, J.I., Verona, C.A., Casal, A.B., Laborde, M.A., 1974. Fitoplancton, pigmentos y condiciones ecológicas del Golfo San Matías: II, noviembre de 1971. In: Anales Informes Comisión de Investigaciones Científicas Provincia de Buenos Aires (La Plata), (10-76 pp).

Casanoves, F., Di Rienzo, J.A., Balzarini, M.G., Gonzalez, L., Tablada, M., Robledo, C.W., 2012. InfoStat. User Manual, Córdoba, Argentina.

Costa, P.R., Garrido, S., 2004. Domoic acid accumulation in the sardine Sardina pilchardus and its relationship to Pseudo-nitzschia diatom ingestion. Mar. Ecol. Prog. Ser. 284, 261-268.

D’Agostino, V.C., Krock, B., Degrati, M., Sastre, A.V., Santinelli, N., Krohn, T., Hoffmeyer, M.S., 2019. Occurrence of toxigenic microalgal species and Phycotoxin, and accumulation in Mesozooplankton in northern Patagonian Gulfs, Argentina. Environ. Toxicol. and Chemistry 38, 2209-2223.

D'Agostino, V.C., Hoffmeyer, M.S., Almandoz, G.O., Sastre, V., Degrati, M., 2015. Potentially toxic Pseudo-nitzschia species in plankton and fecal samples of Eubalaena australis from Península Valdés calving ground, Argentina. J. Sea Res. 106, 39-43.

D'Agostino, V.C., Hoffmeyer, M.S., Degrati, M., 2016. Faecal analysis of southern right whales (Eubalaena australis) in Península Valdés calving ground, Argentina: Calanus australis, a key prey species. J. Mar. Biol. Ass. U.K 96, 859-868.

D'Agostino, V.C., Degrati, M., Santinelli, N., Sastre, V., Dans, S.L., Hoffmeyer, M.S., 2018. The seasonal dynamics of plankton communities, relative to the foraging of the southern right whale (Eubalaena australis) in northern Patagonian gulfs, Península Valdés, Argentina. Cont. Shelf Res. 164, 45-57.

D’Agostino, V.C., Degrati, M., Sastre, V., Santinelli, N., Krock, B., Krohn, T., Dans, S., Hoffmeyer, M.S., 2017. Domoic acid in a marine pelagic food web: exposure of southern right whales Eubalaena australis to domoic acid on the Península Valdés calving ground, Argentina. Harmful Algae 68, 248-253.

Di Rienzo, J.A., Casanoves, F., Balzarini, M.G., Gonzalez, L., Tablada, M., Robledo, C.W., 2016. InfoStat Group, Facultad de Ciencias Agropecuarias, Universidad Nacional de Córdoba, Argentina. http://www.infostat.com.ar.

Dogliotti, A.I., Shloss, I.R., Almandoz, G.O., Gagliardini, D.A., 2009. Evaluation of SeaWiFS and MODIS chlorophyll-a products in the Argentinean Patagonian Continental Shelf (381S-551S). Int. J. of Rem. Sens. 30, 251-273.

Escalera, L., Pazos, Y., Moron, A., Reguera, B., 2007. Noctiluca scintillans may act as a vector of toxigenic microalgae. Harmful Algae 6, 317-320.

Fabro, E., Almandoz, G.O., Ferrario, M.E., Hoffmeyer, M.S., Pettigrosso, R.E., Uibrig, R., Krock, B., 2015. Co-occurrence of Dinophysis tripos and pectenotoxins in Argentinean shelf waters. Harmful Algae 42, 25-33.

Fehling, J., Davidson, E., Bolch, C.J., Bates, S.S., 2004. Growth and domoic acid production by Pseudo-nitzschia seriata (Bacillariophyceae) under phosphate and silicate limitation. J. Phycol. 40 (684-683).

Fernandez Aráoz, N., 1991. Individual biomass, based on body measures, of copepod species considered as main forage items for fishes of the Argentine shelf. Oceanol. Acta 14, 575-580.

Ferrario, M.E., Sar, E.A., Castaños, C., Hinz, F., 1999. Potentially toxic species of the diatom genus Pseudo-nitzschia in Argentinian coastal waters. Nova Hedwigia 68, 131-147.

Finenko, G.A., Kideys, A.E., Anninsky, A.B., Shiganova, T.A., Roohi, A., Tabari, M.R. Rostami, H., Bagheri, S., 2006. Invasive ctenophore Mnemiopsis leidyi in the Caspian Sea: feeding, respiration, reproduction and predatory impact on the zooplankton community. Mar. Ecol. Prog. Ser. 314, 171-185.

Fire, S.E., Wang, Z.H., Berman, M., Langlois, G.W., Morton, S.L., Sekula-Wood, E., Benitez-Nelson, C.R., 2010. Trophic transfer of the harmful algal toxin domoic acid as a cause of death in a minke whale (Balaenoptera acutorostrata) stranding in southern California. Aq. Mamm. 36, 342-350.

Gagliardini, D.A., Rivas, A.L., 2004. Environmental characteristics of san Matías gulf obtained from Landsat-TM and ETM + data. Gayana 68, 186-193.

Garcia, M.D., Hoffmeyer, M.S., Abbate, M.C.L., Barria de Cao, M.S., Almandoz, G.O., Hernando, M.P., Schloss, I.R., 2016. Micro- and mesozooplankton responses during two contrasting summers in a coastal Antarctic environment. Polar Biol. 39, 123-137.

Grebner, W., Berglund, E.C., Berggren, F., Eklund, J., Harðardóttir, S., Anderson, M.X., Selander, E., 2019. Induction of defensive traits in marine plankton-new copepodamide structures. Limnol. \& Oceanogr. Mar 64, 820-831.

Hansson, L.J., Moeslund, O., Kiørboe, T., Riisgard, H.U., 2005. Clearance rates of jellyfish and their potential predation impact on zooplankton and fish larvae in a neritic ecosystem (Limfjorden, Denmark). Mar. Ecol. Prog. Ser. 304, 117-131.

Harðardóttir, S., Pančić, M., Tammilehto, A., Krock, B., Møller, E.F., Nielsen, T.G., Lundholm, N., 2015. Dangerous relations in the Arctic marine food web: interactions between toxin producing Pseudo-nitzschia diatoms and Calanus copepodites. Marine Drugs 13, 3809-3835.
Hasle, G.R., 1978. The inverted-microscope method. Chapter 5.2.1 in phytoplankton manual. In: Sournia, A. (Ed.), United Nations Educational, Scientific and Cultural Organization. Paris, France.

Kogan, M., 2005. Estudio de la composición específica, abundancia y distribución espacial del microzooplancton (protozoos y micrometazoos) en el estuario del Río de la Plata (Argentina-Uruguay). Ph. D. Thesis. Universidad de Buenos Aires, Buenos Aires, Argentina.

Krock, B., Tillmann, U., John, U., Cembella, A.D., 2008. LC-MS/MS on board ship tandem mass spectrometry in the search for phycotoxins and novel toxigenic plankton from the North Sea. Anal. Bioanal. Chem. 392, 797-803.

Krock, B., Borel, C.M., Barrera, F., Tillmann, U., Fabro, E., Almandoz, G.O., Ferrario, M.E., Garzón Cardona, J.E., Koch, B.P., Alonso, C., Lara, R., 2015. Analysis of the hydrographic conditions and cyst beds in the San Jorge Gulf, Argentina, that favor dinoflagellate population development including toxigenic species and their toxins. J. Mar. Syst. 148, 86-100.

Leandro, L.F., Teegarden, G.J., Roth, P.B., Wang, Z.H., Doucette, G.J., 2010a. The copepod Calanus finmarchicus: a potential vector for trophic transfer of the marine algal biotoxin, domoic acid. J. Exp. Mar. Biol. and Ecol. 382, 88-95.

Leandro, L.F., Rolland, R.M., Roth, P.B., Lundholm, N., Wang, Z.H., Doucette, G.J., 2010b. Exposure of the North Atlantic right whale Eubalaena glacialis to the marine algal biotoxin, domoic acid. Mar. Ecol. Prog. Ser. 398, 287-303.

Lefebvre, K.A., Bargu, S., Kieckhefer, T., Silver, R.M.W., 2002. From sanddabs to blue whales: the pervasiveness of domoic acid. Toxicon 40, 971-977.

Lelong, A., Hégaret, H., Soudant, P., Bates, S.S., 2012. Pseudo-nitzschia (Bacillariophyceae) species, domoic acid and amnesic shellfish poisoning: revisiting previous paradigms. Phycologia 51, 168-216.

Lincoln, J.A., Turner, J.T., Bates, S.S., Leger, C., Gauthier, D.A., 2001. Feeding, egg production, and egg hatching success of the copepods Acartia tonsa and Temora longicornis on diets of the toxic diatom Pseudo-nitzschia multiseries and the nontoxic diatom Pseudo-nitzschia pungens. Hydrobiologia 453, 107-120.

Loureiro, S., Jauzein, C., Garcés, E., Collos, Y., Camp, J., Vaqué, D., 2009. The significance of organic nutrients in the nutrition of Pseudo-nitzschia delicatissima (Bacillariophyceae). J. Plankton Res. 31, 399-410.

Bacillariophyceae. In: Lundholm, N. (Ed.), IOC-UNESCO Taxonomic Reference List of Harmful Micro Algae, Available online at. http://www.marinespecies.org/hab (Accessed on 2019-04-15).

Lundholm, N., Harðardóttir, S., 2017. Lab-rat diatoms and their grazers- toxic diatoms and copepods. Harmful Algae News 56.

Lundholm, N., Hansen, P.J., Kotaki, Y., 2004. Effect of pH on growth and domoic acid production by potentially toxic diatoms of the genera Pseudo-nitzschia and Nitzschia. Mar. Ecol. Prog. Ser. 273, 1-15.

Lundholm, N., Krock, B., John, U., Skov, J., Cheng, J., Pančić, M., Wohlrab, S., Rigby, K., Nielsen, T.G., Selander, E., Harðardóttir, S., 2018. Induction of domoic acid production in diatoms - types of grazers and diatoms are important. Harmful Algae 79, $64-73$.

Maldonado, M.T., Hughes, M.P., Rue, E.L., Wells, M.L., 2002. The effect of Fe and cu on growth and domoic acid production by Pseudo-nitzschia multiseries and Pseudo-nitzschia australis. Limnol. Oceanogr. 47, 515-526.

Maneiro, I., Iglesias, P., Guisande, C., Riveiro, I., Barreiro, A., Zervoudaki, S., Graneli, E., 2005. Fate of domoic acid ingested by the copepod Acartia clausi. Mar. Biol. 148, $123-130$.

Marchetti, A., Trainer, V.L., Harrison, P.J., 2004. Environmental conditions and phytoplankton dynamics associated with Pseudo-nitzschia density and domoic acid production in the Juan de Fuca eddy. Mar. Ecol. Prog. Ser. 281, 1-12.

Marchetti, A., Maldonado, M.T., Lane, E.S., Harrison, P.J., 2006. Iron requirements of the pennate diatom Pseudo-nitzschia: comparison of oceanic (high-nitrate, low-chlorophyll waters) and coastal species. Limnol. Oceanogr. 51, 2092-2101.

Marchetti, A., Lundholm, N., Kotaki, Y., Hubbard, K., Harrison, P.J., Armbrust, V.E., 2008. Identification and assessment of domoic acid production in oceanic Pseudo nitzschia (Bacillariophyceae) from iron-limited waters in the northeast subarctic Pacific. J. Phycol. 44, 650-661.

McCabe, R.M., Hickey, B.M., Kudela, R.M., Lefebvre, K.A., Adams, N.G., Bill, B.D., Gulland, F.M.D., Thomson, R.E., Cochlan, W.P., Trainer, V.L., 2016. An unprecedented coastwide toxic algal bloom linked to anomalous ocean conditions. Geophys. Res. Lett. 43, 10366-10376.

McHuron, E.A., Greig, D.J., Colegrove, K.M., Fleetwood, M., Spraker, T.R., Gulland, F.M.D., Harvey, J.T., Lefebvre, K.A., Frame, E.R., 2013. Domoic acid exposure and associated clinical signs and histopathology in Pacific harbor seals (Phoca vitulinarichardii). Harmful Algae 23, 28-33.

McKibben, S.M., Peterson, W., Wood, M., Trainer, V.L., Hunter, M., White, A.E., 2017. Climatic regulation of the neurotoxin domoic acid. Proc. Natl. Acad. Sci. U. S. A. 114, 239-244.

Miesner, A.K., Lundholm, N., Krock, B., Nielsen, T.G., 2016. The effect of Pseudo-nitzschia seriata on grazing and fecundity of Calanus finmarchicus and Calanus glacialis. J. Plankton Res. 38, 564-574.

Muxagata, E., Amaral, W.J., Barbosa, C.N., 2012. Acartia tonsa production in the Patos lagoon estuary, Brazil. ICES Jour. Mar. Sci. 69, 475-482.

Negri, R.M., Inza, D., 1998. Some potentially toxic species of Pseudo-nitzschia in the argentine sea $\left(35^{\circ}-39^{\circ}\right.$ S). In: Reguera, B., Blanco, J., Fernández, M.L., Wyatt, T. (Eds.), Harmful Algae. Xunta de Galicia and IOC of UNESCO Publishers, pp. 84-85.

Negri, R.M., Montoya, N.G., Carreto, J.I., Akselman, R., Inza, D., 2004. Pseudo-nitzschia australis, Mytilus edulis, Engraulis anchoita, and domoic acid in the Argentine Sea. In: Steidinger, K.A., Landsberg, J.H., Tomas, C.R., Vargo, G.A. (Eds.), Harmful Algae 2002. Florida Fish and Wildlife Conservation Commission, Florida Institute of Oceanography, and Intergovernmental Oceanographic Commission of UNESCO, St. Petersburg, Florida, USA, pp. 139-141. 
Olson, M.B., Lessard, E.J., 2010. The influence of the Pseudo-nitzschia toxin, domoic acid, on microzooplankton grazing and growth: a field and laboratory assessment. Harmful Algae 9, 540-547.

Olson, M.B., Lessard, E.J., Cochlan, W.P., Trainer, V.L., 2008. Intrinsic growth and microzooplankton grazing on toxigenic Pseudo-nitzschia spp. diatoms from the coastal Northeast Pacific. Limnol. Oceanogr. 53, 1352-1368.

Paparazzo, F.E., Bianucci, L., Schloss, I.R., Almandoz, G.O., Solís, M., Esteves, J.L., 2010. Cross-frontal distribution of inorganic nutrients and chlorophyll- $a$ on the Patagonian continental shelf of Argentina during summer and fall. Rev. Biol. Mar. Oceanogr. 45, 107-119.

Parsons, M.L., Dortch, Q., Turner, R.E., 2002. Sedimentological evidence of an increase in Pseudo-nitzschia (Bacillariophyceae) density in response to coastal eutrophication. Limnol. Oceanogr. 47, 551-558.

Peters, R.H., Downing, J.A., 1984. Empirical analysis of zooplankton filtering and feeding rates. Limnol. Oceanogr. 29, 763-784.

Petz, W., 1999. Ciliophora. In: Boltovskoy, D. (Ed.), South Atlantic Zooplankton. Backhuys Publishers, Leiden, pp. 265-319.

Piola, A.R., Palma, E.D., Bianchi, A.A., Castro, B.M., Dottori, M., Guerrero, R.A., Marrari, M., Matano, R.P., Möller Jr., O.O., Saraceno, M., 2018. Physical oceanography of the SW Atlantic shelf: A review. In: Hoffmeyer (Ed.), Plankton ecology of the Southwestern Atlantic. Springer, pp. 37-46.

Pisoni, J.P., Rivas, A.L., Piola, A.R., 2014. Satellite remote sensing reveals coastal upwelling events in the San Matías Gulf-Northern Patagonia. Rem. Sens. Environ. 152, 270-278.

Prygiel, J., Coste, M., 2000. Guide Métodologique pour la mise en oeuvre de l'Indice Biologique Diatomées. In: NF T 90-354. Artois-Picardie, Cemagref Bordeaux, Douai, Agence de l'eau.

Rivas, A.L., Beier, E.J., 1990. Temperature and salinity fields in the Northpatagonic gulfs. Oceanol. Acta 13, 15-20.

Sabatini, M.E., Martos, P., 2002. Mesozooplakton features in a frontal area off northern Patagonia (Argentina) during spring 1995-1998. Sci. Mar. 66, 215-232.

Sastre, A., Santinelli, N., Esteves, J., Ferrario, M., 2001. Aspectos ecológicos de especies de Pseudo-nitzschia en aguas costeras patagónicas (Argentina). In: Alveal, K., Antezana, T. (Eds.), Sustentabilidad de la biodiversidad. Universidad de Concepción, Concepción, Chile, pp. 217-235.

Sastre, A., Santinelli, N., Marino, G., Solís, M., Pujato, L., Ferrario, M., 2007. First detection of domoic acid produced by Pseudo-nitzschia species, Chubut coastal waters, Patagonia, Argentina. Harmful Algae News 34, 12-14.

Sato, N.E., Hernández, D., Viñas, M.D., 2004. Hábitos alimentarios de Noctiluca scintillans en aguas costeras de la Provincia de Buenos Aires, Argentina. Lat. Am. J. Aquat. Res. $38,403-412$.

Schnetzer, A., Miller, P.E., Schaffner, R.A., Stauffer, B.A., Jones, B.H., Weisberg, S.B., Di Giacomo, P.M., Berelson, W.M., Caron, D.A., 2007. Blooms of Pseudo-nitzschia and domoic acid in the San Pedro Channel and Los Angeles harbor areas of the Southern California Bight, 2003-2004. Harmful Algae 6, 372-387.

Schnetzer, A., Lampe, R.H., Benitez-Nelson, C.R., Marchetti, A., Osburn, C.L., Tatters, A.O., 2017. Marine snow formation by the toxin-producing diatom, Pseudo-nitzschia australis. Harmful Algae 61, 23-30.

Scholin, C.A., Gulland, F., Doucette, G.J., Benson, S., Busman, M., Chavez, F.P., Cordaro, J., DeLong, R., De Vogelaere, A., Harvey, J., Haulena, M., Lefebvre, K., Lipscomb, T., Loscutoff, S., Lowenstine, L.J., Marin, R., Miller, P.E., McLellan, W.A., Moeller, P.D.R., Powell, C.L., Rowles, T., Silvagni, P., Silver, M., Spraker, T., Trainer, V., Van Dolah, F.M., 2000. Mortality of sea lions along the Central California coast linked to a toxic diatom bloom. Nature 403, 80-83.

Sekula-Wood, E., Schnetzer, A., Benitez-Nelson, C.R., Anderson, C., Berelson, W.M. Brzezinski, M.A., Burns, J.M., Caron, D.A., Cetinic, I., Ferry, J.L., Fitzpatrick, E., Jones, B.H., Miller, P.E., Morton, S.L., Schaffner, R.A., Siegel, D.A., Thunell, R., 2009 Rapid downward transport of the neurotoxin domoic acid in coastal waters. Nat. Geosci. 2, 272-275.
Selander, E., Kubanek, J., Hamberg, M., Andersson, M.X., Cervin, G., Pavia, H., 2015. Predator lipids induce paralytic shellfish toxins in bloom-forming algae. PNAS 112, 6395-6400.

Selander, E., Berglund, E.C., Engström, P., Berggren, F., Eklund, J., Harðardóttir, S., Lundholm, N., Grebner, W., Anderson, M.X., 2019. Copepods drive large-scale traitmediated effects in marine plankton. Science Advances 5 (2), eaat5096. https://doi. org/10.1126/sciadv.aat5096.

Sieburth, J.N., Smetacek, V., Lenz, J., 1978. Pelagic ecosystem structure: heterotrophic compartments of the plankton and their relationship to plankton size fractions. Limnol. Oceanogr. 23, 1256-1263.

Strickland, J.D., Parsons, T.R., 1972. A practical handbook of seawater analysis. In: Fishery Research Board of Canada. Bulletin 167 (Second Edition). Otawa.

Sunesen, I., Bárcena, A., Sar, E.A., 2009. Diatomeas potencialmente nocivas del Golfo San Matías (Argentina). Rev. Biol. Mar. Oceanogr. 44, 67-88.

Tammilehto, A., Nielsen, T.G., Krock, B., Møller, E.F., Lundholm, N., 2012. Calanus spp.vectors for the biotoxin, domoic acid, in the Arctic marine ecosystem? Harmful Algae $20,165-174$.

Tammilehto, A., Nielsen, T.G., Krock, B., Møller, E.F., Lundholm, N., 2015. Induction of domoic acid production in the toxic diatom Pseudo-nitzschia seriata by calanoid copepods. Aquat. Toxicol. 159, 52-61.

Tester, P.A., Pan, Y., Doucette, G., 2001. Accumulation of domoic acid activity in copepods. In: Hallegraeff, G.M., Blackburn, S.I., Bolch, C.J., Lewis, R.J. (Eds.), Harmful algal blooms 2000. Intergovernmental oceanographic commission of UNESCO, pp. 418-421.

Tonini, M.H., Palma, E.D., Piola, A.R., 2013. A numerical study of gyres, thermal fronts and seasonal circulation in austral semi-enclosed gulfs. Cont. Shelf Res. 65, 97-110.

Trainer, V.J., Adams, N.G., Bill, B.D., Stehr, C.M., Wekell, J.C., Moeller, P., Busman, M., Woodruff, D., 2000. Domoic acid production near California current upwelling zones, June 1998. Limnol. Oceanogr. 45, 1818-1833.

Trainer, V.L., Hickey, B.M., Lessard, E.J., Cochlan, W.P., Trick, C.G., Wells, M.L., MacFadyen, A., Moore, S.K., 2009. Variability of Pseudo-nitzschia and domoic acid in the Juan de Fuca eddy region and its adjacent shelves. Limnol. Oceanogr. 54, 289-308.

Trainer, V.L., Bates, S.S., Lundholm, N., Thessen, A.E., Cochlan, W.P., Adams, N.G., Trick, C.G., 2012. Pseudo-nitzschia physiological ecology, phylogeny, toxicity, monitoring and impacts on ecosystem health. Harmful Algae 14, 271-300.

Trainer, V.L., Moore, S.K., Hallegraeff, G., Kudela, R.M., Clement, A., Mardones, J.I., Cochlan, W.P., 2019. Pelagic harmful algal blooms and climate change: lessons from nature's experiments with extremes. Harmful Algae 91, 101591. https://doi.org/10. 1016/j.hal.2019.03.009.

Turner, J.T., 2014. Planktonic marine copepods and harmful algae. Harmful Algae 32, 81-93.

Williams, G.N., Sapoznik, M., Ocampo-Reinaldo, M., Solís, M., Narvarte, M., González, R., Esteves, J.L., Gagliardini, D.A., 2010. Comparison of AVHRR and SeaWiFS imagery with fishing activity and in-situ data in san Matías gulf, Argentina. Int. J. Rem. Sens. 31, 4531-4542.

Williams, G.N., Dogliotti, A.I., Zaidman, P., Solís, M., Narvarte, M.A., González, R.C., Esteves, J.L., Gagliardini, D.A., 2013. Assessment of remotely-sensed sea-surface temperature and chlorophyll-a concentration in san Matías gulf (Patagonia, Argentina). Cont. Shelf Res. 52, 159-171.

Wilson, C., Sastre, A.V., Hoffmeyer, M.S., Rowntree, V.J., Fire, S.E., Santinelli, N.H., Diaz Ovejero, S., D’Agostino, V., Maron, C.F., Doucette, G.J., Broadwater, M.H., Wang, Z., Montoya, N., Seger, J., Alder, F.R., Sironi, M., Uhart, M.M., 2015. Southern right whale (Eubalaena australis) calf mortality at Península Valdés, Argentina: are harmful algal blooms to blame? Mar. Mamm. Sci. 32, 423-451.

Windurst, A., 1992. The responses of bacteria, microalgae and zooplankton to the diatom, Nitzschia pungens f. multiseries and its toxic metabolite domoic acid. MS. Thesis. Dalhousie Univ, USA.

Zar, J.H., 1999. Biostatistical Analysis. Prentice Hall Inc, Upple Saddle River, New Jersey, USA. 